\title{
Popular Music in Southeast Asia
}

\section{Banal Beats,}

\section{Muted Histories}

Bart Barendregt, Peter Keppy, and Henk Schulte Nordholt

Amsterdam University Press 
Popular Music in Southeast Asia 



\title{
Popular Music in Southeast Asia
}

\author{
Banal Beats, Muted Histories
}

Bart Barendregt, Peter Keppy, and Henk Schulte Nordholt 
Cover image: Indonesian magazine Selecta, 31 March 1969

KITLV collection. By courtesy of Enteng Tanamal

Cover design: Coördesign, Leiden

Lay-out: Crius Group, Hulshout

Amsterdam University Press English-language titles are distributed in the US and Canada by the University of Chicago Press.

$\begin{array}{ll}\text { ISBN } & 9789462984035 \\ \text { e-ISBN } & 9789048534555 \text { (pdf) } \\ \text { DOI } & 10.5117 / 9789462984035 \\ \text { NUR } & 660\end{array}$

\section{(c) $(1) \Theta$}

Creative Commons License CC BY NC ND (http://creativecommons.org/ licenses/by-nc-nd/3.o)

@ All authors / Amsterdam University Press B.V., Amsterdam 2017

Some rights reserved. Without limiting the rights under copyright reserved above, any part of this book may be reproduced, stored in or introduced into a retrieval system, or transmitted, in any form or by any means (electronic, mechanical, photocopying, recording or otherwise). 


\section{Table of Contents}

Introduction $\quad 9$

Muted sounds, obscured histories 10

Living the modern life $\quad 11$

Four eras 13

Research project Articulating Modernity $\quad 15$

1 Oriental Foxtrots and Phonographic Noise,

1910s-1940s 17

New markets $\quad 18$

The rise of female stars and fandom $\quad 24$

Jazz, race, and nationalism $\quad 28$

Box 1.1 Phonographic noise 34

Box 1.2 Dance halls 34

Box 1.3 The modern woman $\quad 36$

2 Jeans, Rock, and Electric Guitars, 1950s-mid-196os 39

Youth culture 40

Moral indignation $\quad 44$

Local industry $\quad 45$

Beat goes local $\quad 47$

Box 2.1 Gangs $\quad 5^{1}$

Box 2.2 Blue Jeans $\quad 5^{1}$

Box 2.3 Tremolo guitar 52

3 The Ethnic Modern, 1970s-1990s 55

Modern music for the Muslim Malay masses $\quad 55$

Pop history, as we know it $\quad 58$

Subversive sounds $\quad 61$

Making noise in the big melting pot 64

What is so modern about the ethnic? 66

The sound of longing for home: pop Minang 69

Village girl and big city pop diva: The story of Elly

Kasim $\quad 71$ 
$\begin{array}{lll}\text { Box 3.1 Disco } & 73\end{array}$

Box 3.2 Dangdut 74

Box 3.3 Going abroad (in two songs) 75

4 Doing it Digital, 1990s-20oos 79

Musical revolutions: Finally indie-pendent? 80

Pop, politics, and piety $\quad 84$

Asia around the corner $\quad 87$

Doing it Digital: Three apparent paradoxes 90

The Malay Muslim girl-next-door: A deeper conversation with Yuna $\quad 93$

Box 4.1 JKT48 96

Box 4.2 An Indonesian indie song 97

Box 4.3 Karaoke discs 97

Box 4.4 SoundCloud communities $\quad 98$

$\begin{array}{ll}\text { Selected Bibliography } & 101\end{array}$

\section{List of Illustrations}

1 A Malay dondang sayang song recorded in Singapore by Pagoda Record, subsidiary of Deutsche Grammophon, $c .1935$

2 Quranic text interpretation (tafsir) and translation from Arabic to Malay by a female religious expert (ustazah) recorded by Extra Records (His Master's Voice) in Indonesia, c. 1938

3 Rajuan Irama, an Malay orchestra, c. 1935

4 Two Europeans dressed Filipino-style representing 'Manila Jazz', Indonesia, c. 1920s

5 Modern jazz music was also regularly associated with noise, as evidenced by this advertisement for a medicine to combat headaches. Published in periodical D'Orient, Netherlands East Indies, 1936 
6 Eurasian Malay opera actor, playwright, director, singer and popular recording artist, P.W.F. Cramer, accompanied by a Malay opera leading lady (sri panggung) from Betawi (present-day Jakarta), standing next to a phonograph equipped with a giant horn, $c .1912$

7 Indonesian popular singer Dinah in modern dress and hair fashion, $c$. 1938. She engaged successfully in kroncong singing competitions in Singapore from 1937 onwards, recorded for HMV in Singapore, and appeared on radio in the Netherlands East Indies in 1940.

8 Brilliantine was an indispensable product for men in the 1950s. It kept the hair well-groomed and gave it the shine.

9 New American dances were tried on the dance floor at social gatherings such as at this Bandung high school party, c. 1957.

10 Fashion-conscious Bandung youth sporting tight jeans, $c .1957$

11 Radio Prambors was launched in 1971 in Jakarta. Airing pop music, Prambors was a teen icon in the 1970s-199os period. Nowadays, Prambors FM is Indonesia's 'No. 1 Hit Music Station'.

12 Sumatran punk youth, 2008

13 Video CD vendor in a market stall

14 \#SoundCloud Meetup YK in the Momento Café, Yogyakarta, 26 February 2014 



\section{Introduction}

Not bound by national borders, popular music has been flowing across the world for over a century. It has been consumed and produced by many, including Southeast Asians. This book offers a concise history of popular music and its social meaning in Southeast Asia. It focuses on the Malay world; that is, present-day Indonesia, Malaysia, and Singapore, with an occasional sidestep to other parts of the region, such as the Philippines and Thailand. The period stretches from popular music's beginnings in the 'Jazz Age' of the 1920s and 1930s, to the first decade of the twenty-first century, with phenomena such as modern Muslim boy bands and digital music sharing.

Popular music matters. Besides offering people leisure, it also has deeper social meaning, and this deserves to be studied. The main thread of this book is how locally produced popular music came into being as a token of modern life, and as a terrain where people, performers, and audiences enjoyed as well as reflected on both the blessings and downsides of modern life in the twentieth century.

Each generation has its stock of cultural heroes and favourite popular tunes. For example, in the 1920 s and 1930s the Javanese singer-actress Miss Riboet was one of the most popular performers in island and peninsular Southeast Asia and the first trans-local female celebrity in the Malay world. Her fame reached from Penang to Manila. She performed and recorded on gramophone an eclectic song repertoire from Javanese folk tunes to Arabic songs. In more recent times, the popular boy band Raihan attracted large crowds in Malaysia and Indonesia during the first decade of this century. Guided by beliefs on Islamic piety, moral purity, and facilitated by the latest in recording technologies, and admired by the rising orthodox middle classes and Muslim activists alike, Raihan merged Western popular music with Malay and Arabic music styles. 
Miss Riboet and Raihan may be separated in time by more than fifty years, they have in common to have married the old with the new and to have connected local traditions with foreign cultural forms. In doing so, they transformed music into something that people conceived as novel and modern, yet at the same time as sufficiently recognizable. Moreover, their songs contained moral lessons, albeit based on different convictions, aimed at educating listeners in order to improve the human condition and to achieve a just society. While Riboet took a secular position, for Raihan religion was clearly a starting point. It is this mix of popular music's novelty and social relevance that appealed to large groups of people.

\section{Muted sounds, obscured histories}

We must bear in mind that, in spite of its long and persistent presence, popular music is ill-defined. The term 'popular' originally designated the notion of 'belonging to the people', but has been used pejoratively to mean 'low' or vulgar culture. Such qualifications indicate that the cultural and social meaning of the popular is questioned and even contested. A more neutral meaning is that of 'widely appreciated', and 'away from a topdown perspective', referring to people's own views. The term is also associated with the spread of mass media. Yet, such takenfor-granted connotations and generalizations tell us little about what popular music contained or meant to people in specific times and places. Popular music has been treated as trivial and banal. Its performers are often muted, and music-loving publics ignored. To gain an understanding of the meaning of popular music, it needs to be contextualized. Popular Music in Southeast Asia situates popular music in the specific socio-historical settings of Southeast Asia's cosmopolitan urban centres.

We can search historical textbooks in vain for mention of popular stars like Miss Riboet and Raihan, their careers, their songs as well as their audiences. Their social and cultural significance 
has largely escaped academic attention. This is no doubt due to deeply ingrained elitist preconceptions of pop music as vulgar and meaningless entertainment for the masses, not worthy of study. Moreover, readings of the past that emphasized the nation and national cultural identity have subdued if not obscured the cross-border practices of innovative actors and their audiences. Hybrid popular music tends to blur or even challenge national identities, rather than enhance or consolidate them. Hence, popular culture habitually becomes the subject of discussion and confusion or, in the case of nationalist historiography, might even evoke opposition or even historical amnesia.

The publication Dance of Life (1998) by American historian Craig A. Lockard stands out as one of the few attempts to seriously consider Southeast Asian popular music as a political, social, and cultural force in its own right. Lockhard's project was geared heavily towards popular music as a channel of political protest for Southeast Asian artists under post-colonial authoritarian regimes. Popular Music in Southeast Asia expands on his pioneering work while taking on the dynamic interplay between audiences, artists, and the culture industry. Its focus is on the lure of modernity in post-colonial as well as colonial settings.

The elusive phenomenon of modernity can be understood as a set of ideas about or even desire for the new, progress, individual choice, innovation, and social and cultural change. Modernity tells us how people thought about and dealt with life in a changing urban environment. Due to its innovative, hybrid, and cross-border nature, popular music, par excellence, has solicited discussions in Southeast Asia about what pertains to modern life.

\section{Living the modern life}

Southeast Asia's centuries-long history of trade, labour migration, and cross-cultural encounters in cities such as Singapore, Kuala Lumpur, Jakarta, Bangkok, and Manila yielded highly diversified 
urban populations and hybrid cultures. For centuries, commercial trading networks linked the region to China, India, the Middle East, and, during the heydays of colonialism, to Europe and America. Locally rooted migrant communities - Chinese, Arab, Tamil - emerged and mixed with the native population. It is therefore no surprise that these surroundings formed the breeding ground for a hybrid popular culture, including popular music and related modern lifestyles of which the outlines dawned in the early twentieth century. Increased capitalist penetration of and far-reaching colonial intervention into local Southeast Asian societies are rooted in the late nineteenth century. It was in the twentieth century, however, that the side effects of these external interventions surfaced more visibly. This is attested to, for example, in the emergence of a multi-ethnic urban and Western-educated 'middle class'. Its members earned their money from white-collar professions in the colonial administration, in the expanding commercial agricultural sector, and in the service sector. No less attracted to modernity than the working classes, these relatively affluent people simply had more money to spend. Moreover, they appeared more inclined towards a Western-oriented lifestyle that helped them to distinguish themselves from the working class as well as from the native aristocratic elites. With the introduction of new, cheaper media technologies in the second half of the twentieth century, like the transistor radio and the audio cassette player, the face of mass consumption altered dramatically. Media technologies became available to larger sections of the less well-to-do sections of society, also outside the cosmopolitan urban centres. These technological changes were of great significance for the development of the culture industries and for the dissemination of popular music in the twentieth century. Needless to say, the development of digital recording technologies and the internet at the end of the millennium had a similar effect.

Rather than seeing consumers of popular music purely in terms of middle- and working-class spectatorship, it is more appropriate to speak of socially differentiated publics in terms 
of generation, gender, peasants to urbanites, ethnic, and religious groups. The intriguing aspect of popular music is that particular genres often appeal to sections of these different groups in society simultaneously. Without suggesting that it has necessarily been a uniting or socially harmonizing force, popular music does cross social groups and, at the same time, it allows people to rally around it, forming new identities. One explanation for this capacity or appeal lies in the fact that the new-fangled music styles formed part of a larger package called 'lifestyle'. How such life styles come into being is a complex process of cultural interaction between producers and consumers. Popular music performers, the culture industry, and print media each in their turn and often working in tandem, provide audiences models fashionable styles, from hairdressing to clothing, codes of conduct, and vernacular languages. The culture industry might manipulate artists and consumers; the industry cannot exert absolute power over consumers. Music lovers are not passive consumers. They have their own preferences and ways of consuming, and identity is not a thing. Identities are imagined and given content and meaning by people who often are not involved in the culture industry and may even rebel against it. In short, popular music offers new means for self-expression and a sense of community, fan groups being the best visible example.

\section{Four eras}

This book is divided into four chapters, each representing pivotal historical junctures: the 1910s to 1940s; the 1950s to mid-196os; the 1970s to 1990s; and finally, the late 1990s up to the first decade of the twenty-first century. In these four eras, technological innovation, human agency, the consumption of new music styles, and the rise of pioneering artists and new audiences converge within particular Southeast Asian urban localities. Artists and their audiences together redefined popular culture, surprising, pleasing, but also confusing and annoying 
others. As they explored artistic, technological, entrepreneurial, and commercial possibilities, artists were put at the forefront of popular culture's production. Visible and audible through the production and consumption of popular music, they made modernity manifest in everyday social life.

Although some overlap of media technology use occurred, each of the four different periods is characterized by a concurrence of new music styles and specific technologies: the gramophone; radio, television, cinema, audio cassettes, CDs, and web-based technologies including YouTube or SoundCloud. And it should be emphasized that throughout the twentieth century, print media, especially newspapers, remained important sources for launching artists into stardom as well as discussing their work and the modern life styles they seemed to propagate.

This book departs from four interlocking sets of questions: (1) Who were the main artists and producers that generated new forms of popular music? What sort of urban environment facilitated the changes they were part of? (2) What was the music like? Which genres were moulded into new styles? What did the music express? (3) Which technologies, ranging from the gramophone to the internet, were appropriated, and how did these technologies facilitate the dissemination and marketing of new music styles? (4) Who were the audiences of new popular music in terms of ethnicity, religion, gender, generation, and class? How was the music received? Were particular lifestyles articulated to mark social distinction, and what does this reveal about the relationship between popular culture and society?

Following the chronology of the suggested periods, four chapters are here presented. Chapter 1, 'Oriental Foxtrots and Phonographic Noise, 1910s-1940s', deals with the Jazz Age. It explores the hybrid nature of a blossoming of popular music and its new (female) stars, adored and consumed by new urban, middle to upper classes in the Philippines and the Netherlands East Indies. Chapter 2, 'Jeans, Rock, and Electric Guitars, 1950smid-196os', traces the emergence of rock and roll, the arrival of youth culture, rock and roll's supposedly subversive nature 
and subsequent moral panics, but also the consolidation of a local music industry in what, by then, were post-independence Malaysia, Indonesia, and the Philippines. Chapter 3, 'The Ethnic Modern, 1970s-199os', analyses the rise of ethnic pop in connection with the spread of music cassettes against the backdrop of emerging regional identities, and rural urban migration, class consciousness, and an articulation of gender differences. Finally, Chapter 4, 'Doing it Digital, 1990s-200os', observes the new opportunities and limitations of disseminating popular music through the web and other related digital social media. It deals with new sorts of emerging fandom, the construction of Asian and Muslim pop as trans-national categories, and points at the paradoxical and ephemeral nature of the new digital era.

Popular Music in Southeast Asia elaborates the complex ways innovations were embedded into continuities, or how new and old trends were linked. It argues, moreover, that, in order to understand the Southeast Asian world of popular music, it is necessary to shift from an exclusive focus on stardom towards a perspective that includes the everyday practices of the countless anonymous and, to a large extent, unrecorded performers and their publics.

\section{Research project Articulating Modernity}

Popular Music in Southeast Asia: Banal Beats, Muted Histories is based on the research project 'Articulating Modernity: The Making of Popular Music in Twentieth-Century Southeast Asia and the Rise of New Audiences (2011-2014)'. This project involved the Royal Netherlands Institute of Southeast Asian and Caribbean Studies (KITLV) in Leiden, the NIOD Institute for War, Holocaust and Genocide Studies in Amsterdam, and the Institute of Cultural Anthropology and Development Sociology of Leiden University. Funding was provided by the Netherlands Organization for Scientific Research (NWO). Articulating Modernity was supervised by Henk Schulte Nordholt and coordinated by senior 
researchers Bart Barendregt and Peter Keppy. PhD students Buni Yani, Lusvita Nuzuliyanti, and Nuraini Juliastuti, and four senior visiting fellows, Ariel Heryanto, Philip Yampolsky, Andrew Weintraub, and Tan Sooi Beng, also contributed to the project. Finally, special mention should be made of Emma Baulch, Dredge Byung'chu Käng, Azmyl Yusof, Brent Luvaas, James Mitchell, Fritz Schenker, and Jeremy Wallach who through their participation in the workshops organized under the project's aegis helped to shape this book. 


\section{$1 \quad$ Oriental Foxtrots and Phonographic Noise, 1910s-1940s}

The 1920 are known worldwide as the Roaring Twenties or Jazz Age. It is a period in between the great world wars when novel forms of commercially driven entertainment emerged, such as the dance hall, recorded music and film, magazines and serial novels, and when radio broadcasting was introduced. Southeast Asia was no exception.

Southeast Asia's Jazz Age tells a story of a vibrant cultural interaction and social transformation. Popular dance music, such as the Charleston, the foxtrot, tango, and, later, the rumba, the venues and its audiences evoked pleasure as much as debate and controversy. Modern popular dance music led people to question and reconstruct boundaries of race, class, national identity, gender, and the modern.

Southeast Asians experimented with music, innovating existing local genres, making the 1920 s and 1930 a period of dynamic cultural change. Almost as a rule in the region, popular music was married to different forms of vernacular theatre. The two started to part company during the almost simultaneous expansion of the phonographic industry, radio broadcasting and the advent of sound film (the 'talkies') in the late 1920s.

This chapter focuses on three themes that highlight the relationship between popular music and society during Southeast Asia's Jazz Age: the record industry, the rise of female stars and fandom, and the link between race, nationalism, and popular music. When Japan invaded the region in December 1941, and within a few months controlled large parts of the area, these dynamic developments in the realm of popular music were suspended for the next four years. 


\section{New markets}

By the turn of the twentieth century, American, and European record companies had recognized the commercial prospects of recording local music in Southeast Asia for local markets. From Burma to Indonesia, local forms of theatre offered a testing ground for these first commercial recordings. In 1903, on the first phonographic recording expedition for the Gramophone Company in Asia, recording engineer Fred Gaisberg noted on a trip to Rangoon, Burma, and his encounter with local artists:

These bright people have an entertainment called a zat. The basis of the drama, which is interspersed with songs and ballet, is the age-old story of a prince and princess. [...] Poe Sein was the most popular actor [...]. His opera company travelled up and down the Irrawaddy River in their own barge and paddle-steamer, something like the show-boat troupes of the Mississippi.

Within a few years, many recording expeditions by different companies followed, documenting songs, scenes like comic dialogues taken from Southeast Asian forms of vernacular theatre, such as the Burmese zat, Malay opera and the Hispano-Filipino zarzuela. This symbiosis between vernacular theatre and the foreign gramophone industry formed the basis for the Southeast Asian entertainment industry to blossom in the 1920 .

The local appetite for recorded music gramophones cannot be understood without acknowledging the profound economic changes that occurred between the late nineteenth century and 1930. In the second half of the nineteenth century, the colonial economies opened up for private capital. As a result, the commercial agricultural sector expanded, and means of transportation and infrastructure improved alongside. Modern shipping and new railroad networks linked the rural hinterlands of peninsular Malaya, Indonesia, and the Philippines to the coastal trade entrepôts. Between 1900 and 1930, up to the Great 
Depression, the colonial economies boomed. Trade volumes increased, particularly of commercial crops like sugar. Migrant (plantation) workers flowed from excess labour areas in China, India, and Java to the estates in Sumatra, mainland Malaya, and the Straits Settlements. The expanding colonial bureaucracies offered new employment opportunities for the native population. The urban-based commerce and service sector expanded as well. Western-style education became available for 'natives', although not at all levels and certainly not at a similar pace in all colonies. As a result of these developments, a Western-educated middle class of government officials, teachers, lawyers, journalists, petty traders, and small-scale industrialists emerged. This emerging middle class covered the political spectrum, from nationalists actively striving for emancipation and independence to people adhering to the colonial status quo. Despite racial divides, economic inequalities, and differences in political loyalties, this group shared a new consumer-oriented lifestyle that set them apart from members of the working class. Their excess income made it possible to subscribe to local newspapers and indulge in modern-style consumerism of fashion, music, dance, and to own new consumer items, such as the gramophone player and a radio set.

When Fred Gaisberg and the other American and European recording engineers that followed in his footsteps set foot on Southeast Asian soil, they knew little about local music and theatre. They had to rely on local intermediaries from the urban middle class, who could introduce them to performers and inform them about upcoming performances. In Thailand, colonial Indonesia, the Straits Settlements, and Malaya, these brokers were often locally based European department store owners or local Chinese shop owners, who were able to communicate in English or another European language. Some of them became local agents for the record companies, others subsidiaries recruiting and recording local musicians. The agents sold gramophone players and related equipment from discs to needles. For many an agent, the music industry was initially a 
side-line. For instance, between 1905 and 1910, the sole agent for German record company Odeon in Singapore was the jeweller Levy Hermanos. Department store Robinson \& Co, also operating from Singapore and the sole agent for the Gramophone and Typewriter Ltd., was probably responsible for selling the first batch of Malay music recorded by Fred Gaisberg in 1903. In 1906, German record company Beka embarked on a recording 'expedition' in Singapore and Batavia, gaining a foothold in Singapore in 1907 through department store Katz Bros. Ltd. In 1903, peranakan Chinese shop owner Tio Tek Hong, whose core retail business was hunting equipment, became sole agent for German record company Odeon in Batavia. One year later, he started releasing records under his own name as Odeon's subsidiary, Tio Tek Hong Records. He was the first to do so in colonial Indonesia. Around 1903, with the aid of local merchant Kee Chiang \& Sons in Bangkok, the British Gramophone Company Ltd. (His Master's Voice, HMV) recorded and released what is believed to have been the first Siamese records. In 1908, a number of Filipino artists from the Hispano-Filipino zarzuela stage, including the famous singer-actress Maria Carpena, took part in a recording session in Manila for the Victor Talking Machine Company. Several of these recordings are songs taken from the Tagalog zarzuela play Walang Sugat ('No wound') written in 1902 by Filipino playwright Severino Reyes. Unlike other artists in surrounding colonies, Filipinos also travelled to the United States to record. One of these earliest known recordings is 'La Sevillana', performed by Banda De La Filipina for Victor's rival in the recording business, Edison, and recorded in New York in 1909.

To feed the appetite for locally recorded homegrown music and theatre plays, the record companies published catalogues for potential clientele in Southeast Asia in the local vernacular, in Malay, Thai, and Hokkien. Local agents and subsidiaries of the foreign record companies also advertised in the newspapers for newly imported and locally recorded songs. Some also offered published song lyric albums and sheet music of local popular music. These printed sources reveal two things. First, that the record 
companies perceived different markets in terms of musical taste and audiences, and second, that a stylistically hybrid popular music that crossed borders was in the making. For example, one rare, surviving Odeon gramophone record catalogue, probably published in 1912, indicates that this German company aimed at non-European audiences in colonial Indonesia, Malaya, and the Straits Settlements (Singapore, Penang, and Malacca). The music styles that are represented in this catalogue are hybrid, but the genres are fixed according to the (alleged) tastes of different ethnic groups, including Chinese migrants and their ethnically mixed offspring. 'Chinese music' is listed separately in Chinese characters from the hybrid music produced and consumed by locally rooted Chinese communities (peranakan or baba). An example of the latter is gambang kromong, with origins in the peranakan Chinese community of Batavia (Jakarta). Another selection of songs classified under 'Singapore Malaju records' includes kroncong, a distinct style of string music with origins in Indonesia, and stambul, derived from a form of Malay opera also with roots in Indonesia. We also find dondang sayang, a distinct musical style popular among Malay-speaking peranakan Chinese on both sides of the Straits of Malacca. This ethnic genre classification seems to have been modelled after the 'race records' current in the American record industry, designed to cater for specific ethnic groups as niche markets.

In the early 1930s, and despite the global economic crisis, the gramophone industry continued to expand in Southeast Asia. A separation between vernacular theatre and a modern popular music industry catering for local audiences became more pronounced. For example, in 1934, record company His Master's Voice in Singapore secured the services of a young man of Minangkabau origin from West Sumatra, named Zubir Said. Thirty years later, he would be known as the composer of Singapore's national anthem. As many of the popular musicians at that time, Said had first worked as a musician in theatres, where his music accompanied silent movies. His favourite instrument was the violin. Later, he joined an itinerant kroncong band that also 
Illustration 1 A Malay dondang sayang song recorded in Singapore by Pagoda Record, subsidiary of Deutsche Grammophon, c. 1935

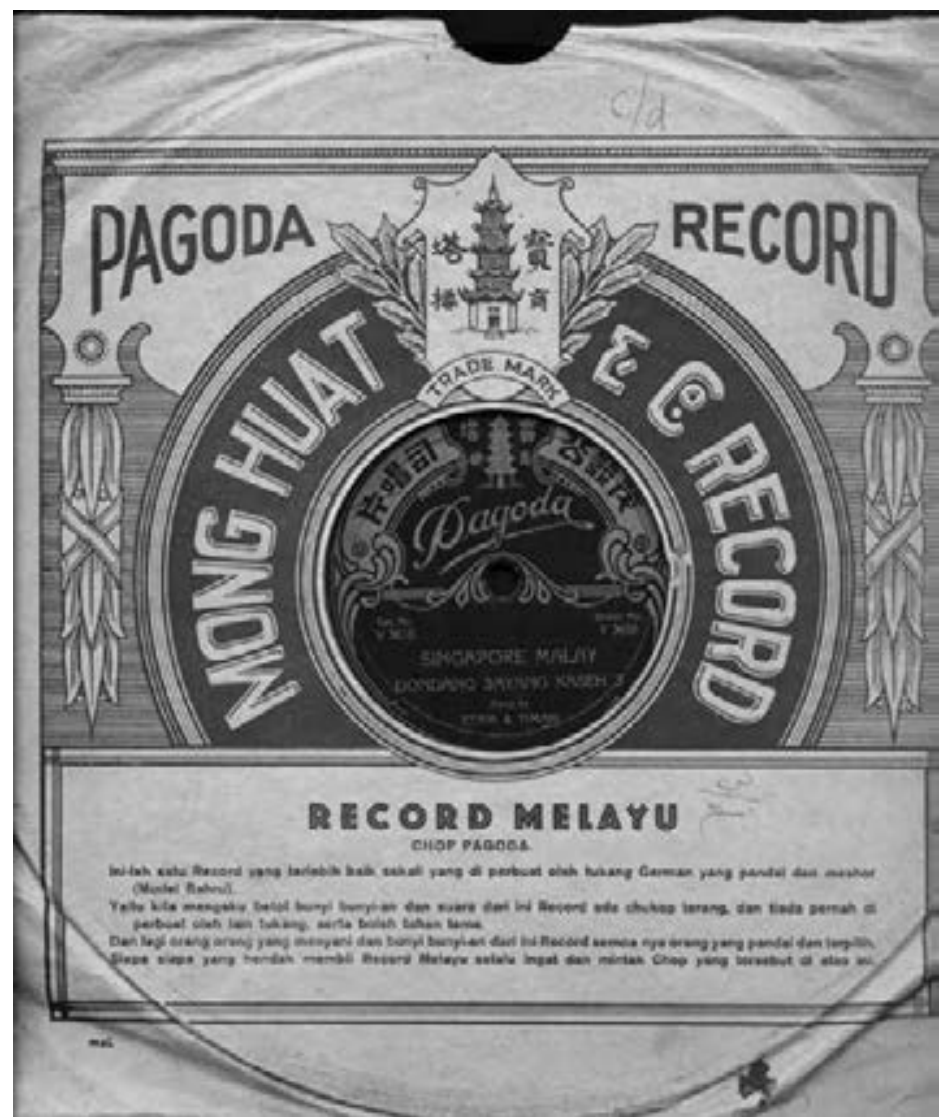

By courtesy of Jaap Erkelens

performed dondang sayang. Kroncong was a mix of Western and native music with origins in nineteenth-century Batavia. In the 1920 and 1930s, it grew into the most popular genre in the Malay world. In Singapore, Said became a member of a bangsawan (Malay opera) troupe that performed at the Happy Valley Park, one of the three big amusement parks in the city. In multi-ethnic 
Singapore, Said was exposed to music that was entirely novel to him: Indian and Chinese music, and Dutch songs. When the Filipino band leader of the Malay opera troupe left, Said took his place. From there, he moved on from studio recording artist for HMV to recording supervisor and later to the position of talent scout. He personally assessed the vocal qualities of kroncong singers in Jakarta, Surabaya, Medan, Penang, and Kuala Lumpur and invited them to record for HMV in Jakarta and Singapore. One of these musical talents was a young man from Surabaya named Said Abdullah.

Said Abdullah Bamazham, of Indonesian-Arab descent, fused local styles such as kroncong with foreign styles such as syncopated jazz, rumba, Hawaiian music, tango and Arab gambus (lute). Through his gramophone recordings for HMV and, later, Canary, his fame spread beyond Java, into Sumatra and Singapore. In addition to his musical talent and popularity, Abdullah is worth mentioning here for two more reasons. First, he used his songs to address pressing social issues. In 'Semangat Baroe' ('New Spirit'), for instance, he describes the anxiety with modern life. In another song, Abdullah's interpretation of the tango, the issue of widespread unemployment, the outcome of the Economic Depression, is raised.

Abdullah is probably the first popular music artist in colonial Indonesia who publicly expressed his sympathy with Indonesian nationalism in commercially recorded songs. For example, his song 'Berani Kerna Benar' ('Courageous because I'm right') released by HMV in late 1936, was prohibited by the Dutch authorities in 1937 for its subversive content. No copies of this banned recorded song are known to have survived. In 1936, Abdullah claimed to have recorded around 150 songs. Among these recordings were several duets with female stars who had carved out a recording career for themselves.

In the mid-1930s, we see another novel development in the realm of popular music in the Malay world: HMV recorded local interpretations of Arabic-Islamic music and Islamic religious instruction performed by local Islamic religious experts and 
Illustration 2 Quranic text interpretation (tafsir) and translation from Arabic to Malay by a female religious expert (ustazah) recorded by Extra Records (His Master's Voice) in Indonesia, C. 1938

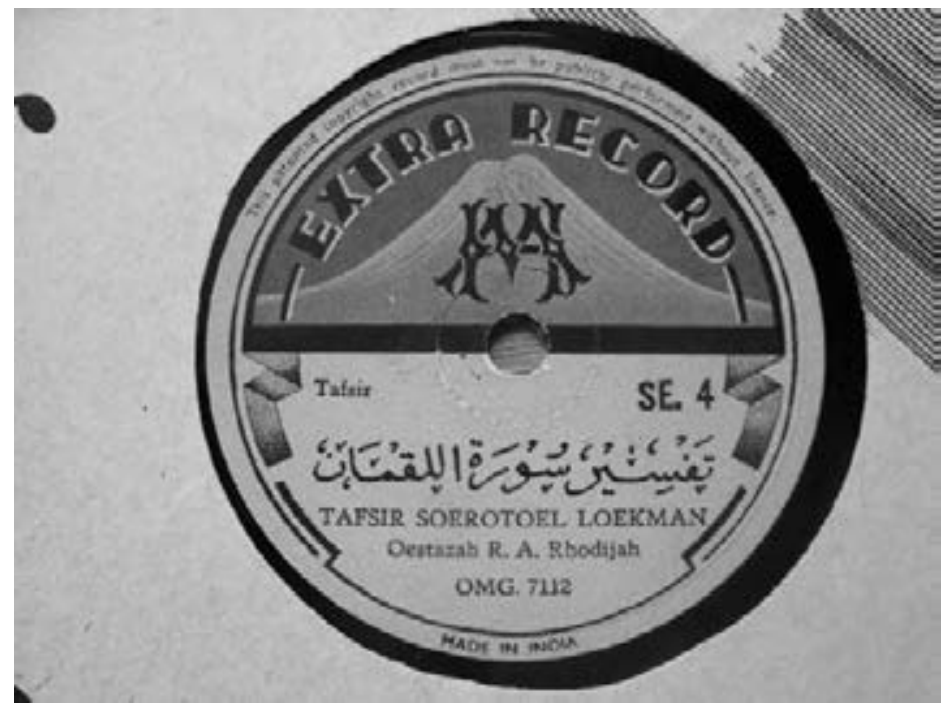

Private collection Peter Keppy

orchestras from the local Arab-Indo community. The Arab genres recorded included qasidah, masri, and nasyid, next to European marches with Arabic lyrics. These records mark the beginning of an early Southeast Asian Islamic popular music. Similar developments would reoccur in the 1980s, with a revival of Islamic pop music in Singapore, Malaysia, and Indonesia (see Chapters 3 and 4).

The rise of female stars and fandom

The marriage between the commercial recording industry and modern local vernacular theatre gave birth to two closely related novel social phenomena: female stardom and fandom. In the 
1920s, singer-actresses started to appear in public, not only in theatres, but also on gramophone records and in the print press, and, in the 1930s, on the radio and the film screen. We are best informed about developments in the Malay world and the Philippines. In colonial Indonesia and Malaya, a brand-new stock of 'Misses' appeared, 'Miss' being a modern and cosmopolitan designation of the new female star. These women were young Eurasian, peranakan Chinese, and native Indonesian singeractresses, many with a background in Malay opera. In the $1920 \mathrm{~s}$ Philippines, Filipina vaudevillians were a novelty. Vaudeville was an eclectic form of theatre offering music, dance, short plays (from condensed Italian operas to vernacular comedies), acrobatics or even sports exhibitions. Some of the vaudevillians were musically educated and experienced artists of the Hispano-Filipino zarzuela stage who moved seamlessly from one stage to another; others were teenagers without any prior stage experience or musical training.

In colonial Indonesia and Malaya, a pioneering example of this new female stardom was Miss Riboet, a Malay opera star of humble Javanese origins who launched her career in 1925. Riboet's assets were her versatility in dancing and singing. Her topical singing (dongengan) in the Malay verse tradition of pantun and syair became her trademark drawing mass audiences. She would improvise in verse, sardonically commenting on daily social affairs. This novelty was highly appreciated by a socially diverse audience of peranakan Chinese, Eurasians, and native Indonesians, many of them belonging to the middle class. Between 1927 and 1932, Miss Riboet recorded on gramophone for German record company Beka. Her song repertoire reveals a broad range of sources: kroncong, Arabic, and Turkish genres, peranakan Chinese music, Javanese and Dutch folk songs, and Malay songs current in Sumatra and the Straits Settlements. Gramophone records and film were among Riboet's main sources of inspiration for her dancing, singing, and acting style. To keep up with the fad of the times and modernity, her band was advertised as a jazz band. Between 1925 and 1941, Riboet 
staged around 350 different light opera plays in what must have been a dazzlingly, yet difficult to estimate, great number of performances spanning almost two decades. She performed in the main cities of the Netherlands East Indies, in the Federated Malay States, the Straits Settlements, Borneo, and even Manila.

There were people who associated Malay opera and Filipino vaudeville with vulgar entertainment, loose morals, and cultural erosion. At the same time, a large group of mostly, but not exclusively, male spectators developed into devotees of vernacular theatre, its music and performers. Fandom was enhanced as female singers appeared on stage, on gramophone records, in the newspapers, in radio broadcasts and, eventually, also in film. As music travelled across national boundaries by gramophone record and radio broadcast, transnational fandom was created. A good example is Filipina singer Priscilla Aristonas, a teenager in the 1930s, who started working for Radio Manila. She received fan mail from the Straits Settlements, India, and Burma, written by males from all ethnic groups, who were delighted with her renderings of American jazz and other popular Anglo-Saxon songs.

In addition to radio, the other media technology that gave rise to female stardom and fandom was cinematography. With the transformation of silent film to 'talkies', cinema theatres mushroomed in urban Southeast Asia in the 1930s. Moreover, local business entrepreneurs took artistic as well as financial interest in the local film industry. Female stars of the theatrical stage and popular singers entered the local film studios that were established in the late 1920s and 1930s. Some of these artists would continue to straddle theatre and film. In the Philippines, vaudevillian Elisabeth Cooper, known as 'Dimples', entered the local cinematographic stage in 1926. Her being kissed on-screen by co-star Luis Tuason aroused controversy and enhanced her fandom in the Philippines. Indonesia's first female film star, singer-actress Roekiyah, appeared in the locally produced blockbuster Terang Boelan ('Full Moon') in 1937. The film and its eponymous title song were a hit in colonial Indonesia, the 
Illustration 3 Rajuan Irama, an Malay orchestra, c. 1935

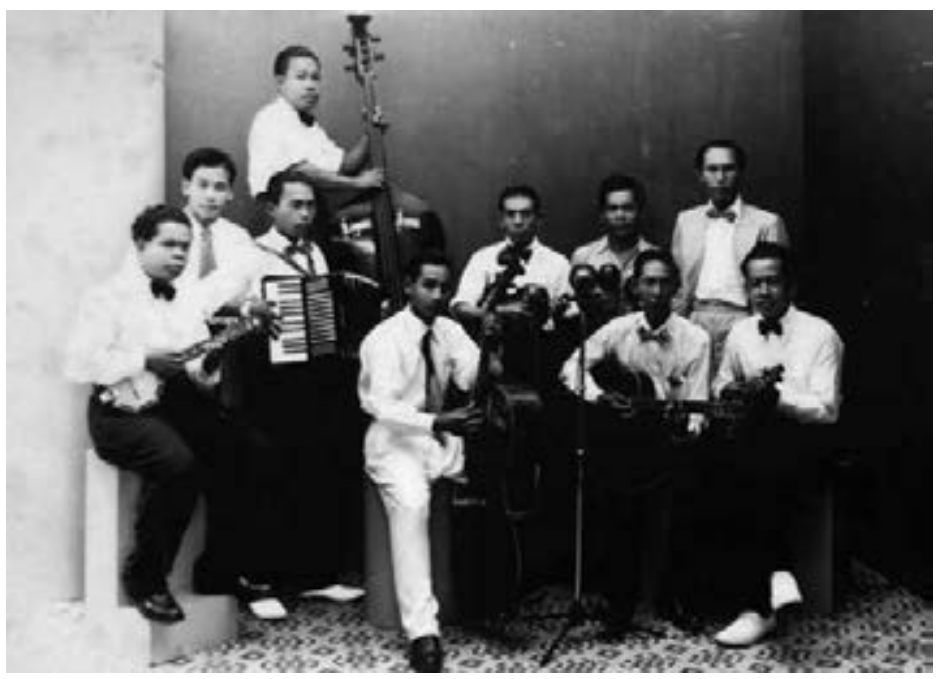

By courtesy of Marije Plomp

Straits Settlements, and mainland Malaya. Many decades later the popular film song proved the basis for a cultural heritage controversy between Malaysia and Indonesia over the origins of the Malaysian anthem Negaraku, its melody believed to have been inspired by the song Terang Bulan. This dispute reveals conflicting cultural nationalisms as well as tensions between popular and 'serious' music.

Fandom also expressed itself in active participation in modern popular culture. For example, in the Straits Settlements, peranakan Chinese established amateur musical and theatrical associations with modern cosmopolitan and Anglo-Americansounding names, such as the Moonlight Minstrels, Merrilads, and Penang Chinese Jazz Lads. The theatrical repertoire, however, consisted of Chinese plays, Malay opera pieces, and modern popular music for social dancing: kroncong and jazz. Proceeds from performances were often reserved for the purpose of charity. The groups performed at various social occasions: Chinese 
religious festivals, and private celebrations from anniversaries to weddings organized by wealthy Chinese businessmen. The Sino-Malay print press greatly contributed to the cultivation of stardom and fandom by publishing the lyrics of popular kroncong and dondang sayang songs, and reporting on live performances and the hugely popular song contests.

\section{Jazz, race, and nationalism}

In the Netherlands East Indies, jazz was certainly perceived as something modern and cosmopolitan. But, unlike the Philippines, it was not seen as something exclusively or necessarily American. Due to the many professional Filipino artists who toured with vaudeville troops and itinerant Malay opera groups in the Netherlands East Indies and Malaya since the early twentieth century, jazz became strongly associated with Filipinos, rather than with (Afro-)Americans. Most Filipino professional musicians had a background in the cosmopolitan urban cultural environment in the Philippines itself. This urban culture was rooted as much in modern American popular entertainment as in a Hispano-Filipino theatrical culture of the late nineteenth century. In the Netherlands East Indies, 'Manilla Jazz' was a household term referring to either a jazz-type musical genre performed by Filipinos or simply a Filipino band. In both cases, the term enhanced the stereotype of Filipinos as 'natural' jazz musicians. Apparently, Europeans in the Netherlands East Indies loved to impersonate them at the popular masquerade balls.

Since the turn of the twentieth century, Filipinos had crossed colonial borders seeking a living in the urban harbour cities of Southeast Asia and coastal China. Music was one of their trades. In the Straits Settlements and in, for example, Medan, North Sumatra, Filipino funeral and municipal town bands built a sound reputation among the wealthy peranakan Chinese and European communities. Filipinos also specialized in jazz-staffed orchestras of international passenger lines, restaurants, theatre, and dance 
Illustration 4 Two Europeans dressed Filipino-style representing ‘Manila Jazz', Indonesia, c. 1920 s

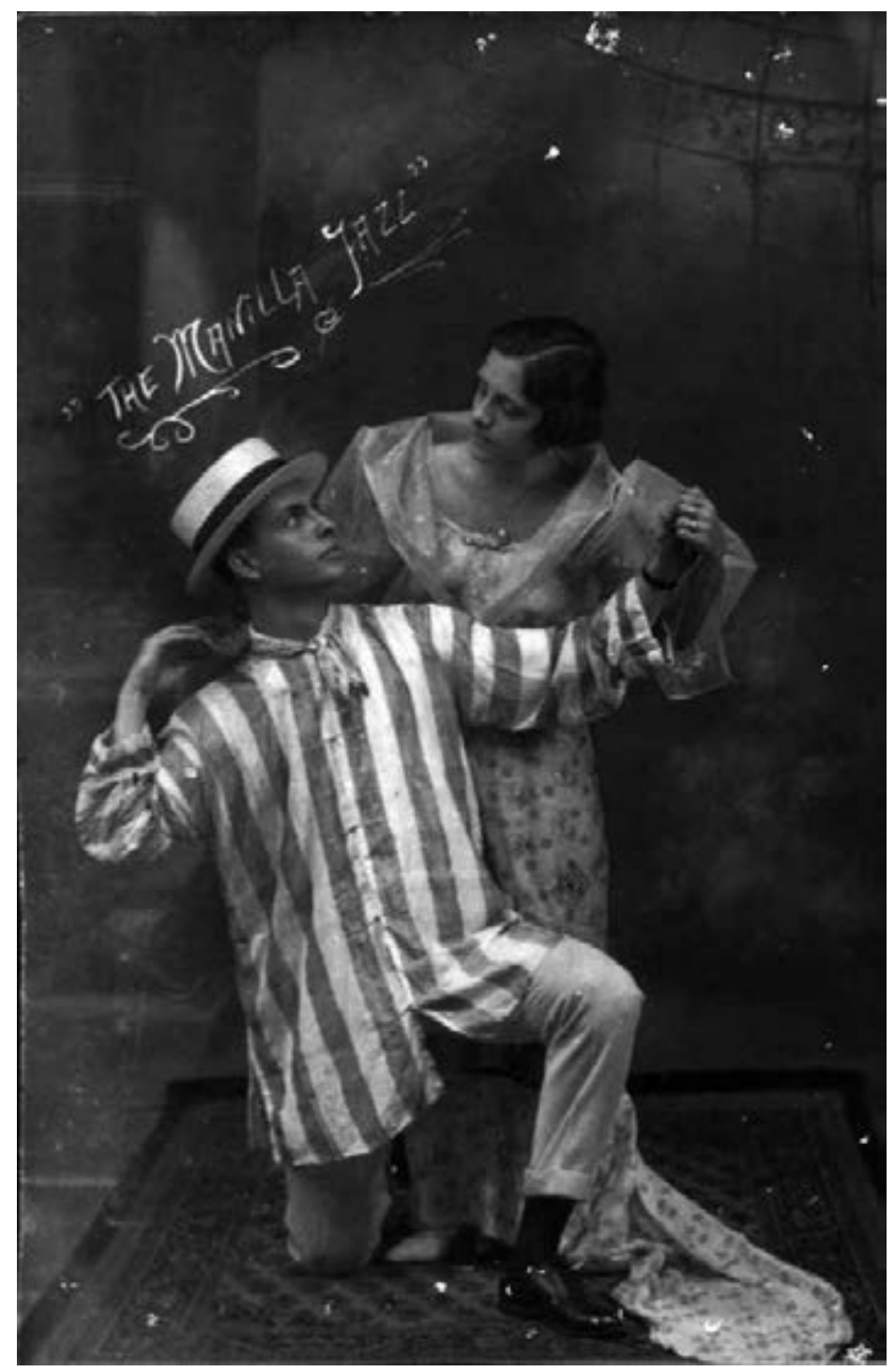

KITLV collection 
halls across Asia. They established private music schools, and, as early as 1904, Filipinos are mentioned in relation to Malay opera. In the 1920s, it was common for members of itinerant Hispano-Filipino vaudeville troupes to seek employment with Malay opera companies as dancers, singers, musicians, and as orchestra leaders. It is thus not surprising that, in 1931, Malay opera star Miss Riboet proudly announced the inclusion of a 'Manila Cabaret' in her show. In Singapore, musically literate Filipinos often directed the multi-ethnic orchestras of Malay opera companies. Peranakan Chinese theatre owners, Malay musicians, and actors held them in high esteem for their musical literacy, professionalism, and skills. This Filipino musical literacy can be largely explained by the musical training that was part of the Christian instruction that many Filipinos had received in their homeland since their childhood. This literacy is also witnessed in the corpus of largely unearthed music of Filipino composers, including popular genres, published on sheet in the 1910 into the 1930s. Prominent poets often wrote the lyrics, either in Spanish or one of the Filipino dialects, linking popular music with literature and the print press. This Filipino music in print appears to have no equivalent in other parts of Southeast Asia.

In Southeast Asia, only a small group from the middle and upper classes had access to jazz and jazz-related styles through gramophone recordings and live performances of touring Hawaiian, Filipino, American, British, and Australian vaudeville artists. Artists presented their own interpretations of jazz or its precursor, the syncopated ragtime music, the basis of a number of modern dances such as the foxtrot. Hawaiian vaudeville troupes are a good example. In the late 1910s, the first Hawaiian dance and music troupe appeared on the Southeast Asian horizon. The Hawaiians moved within the parameters of vaudeville. Hawaiian music itself was a hybrid product of Austrian waltzes, military marches, Christian hymns, and native Hawaiian music that, in the 1910s, was developing under the influence of Afro-American syncopated music and, later, jazz. Ragtime was a musical style with origins in military march music and Afro-American 
syncopated rhythms. In the 1910s, this was the style that lay at the basis of the modern dances like the one-step, two-step, foxtrot, and Charleston, and was one of the main sources of what, after 1917, came to be widely known as 'jazz'. In 1919, ukulele and mandolin virtuoso, recording artist, and business entrepreneur Ernest Kaai from Honolulu was the first Hawaiian artist to tour Southeast Asia. He would return several times throughout the 1920s. The novel sounds created with the steel guitar and ukulele, the accompanying hula dances, Kaai's interpretations of popular jazz songs, the lightning effects, costumes, and settings created a Hawaiian craze in Burma, Malaya, and Indonesia in the early twenties that would last way into the 1930s. Local ensembles would incorporate the Hawaiian guitar into their musical repertoires. In the Philippines, a local industry of handcrafted ukuleles developed.

In the 1910s and 1920s, Filipinos experimenting with and recording Afro-American and Hispano-Filipino music was the rule rather than an exception. One of those artists who engaged in this musical mixing and interpreting was Luis Borromeo, dubbed the Filipino 'King of Jazz'. His active professional career took off on the American vaudeville stage and would span from 1915 to 1941. Throughout his vaudevillian career in the United States, Luis employed an on- and off-stage image. On-stage he appeared as a 'yellow-face act', an orientalist Chinese act. Off-stage, however, Borromeo took pride in being a Filipino and explicitly advocated Philippine independence. In 1921, he returned to the Philippines, toured the islands intensively performing and bringing provincial talent to Manila pioneering a novel localized vaudeville that would turn immensely popular in the 1920s.

The 'jazz' produced by Borromeo was ragtime, and this was common practice among his compatriots. Sheet music published in this period reveals that many Filipino composers, some associated with classical music and Spanish theatre, experimented with modern dance music and Hispano-Filipino genres such as kundiman. They created 'himno-one-step', 'Filipino foxtrot', 'tango-foxtrot', and 'Filipino tango-foxtrots'. For example, in 1918, 
Benito Trapaga composed and published a 'nuevo foxtrot' titled 'Hispano-Filipino'. By the mid-1920s, he had become an accomplished phonographic recording artist for Parlophone, a German company. In 1924, the production of local popular hybrid dance music gained momentum. That year, department store Becks at the Escolta, Manila's main shopping street, started advertising for new 'Filipino Dance Records'. This included foxtrots, onesteps, and waltzes, all created by respected Filipino composers such as Francisco Santiago, Jose Estella, Juan Silos, and several others. These composers have been strongly associated with European classical music and music for zarzuela, and are generally credited for having revived an interest in Filipino native music, in particular the kundiman genre. Their contribution to Filipino popular dance music remains underrated, again illustrating the strained relationship between the popular and the serious.

A small but influential group of Filipino intellectuals and nationalists increasingly expressed their worries about the burgeoning popular culture that came in the wake of the American presence in the Philippines that had begun in 1898. Anxiety about the alien and about modernity peaked during the Great War when a moral panic swept the islands. The United States refused to grant the Philippines unconditional independence. In response, modern dance and music, jazz, and vaudeville, came under vehement attack from Filipino cultural purists, cultural nationalists, and moralists. This turned into a moral crusade against dance halls (see box 2) and in some provinces even led to legislation prohibiting Filipinas to bob their hair. Sections of the elite genuinely believed that Filipino cultural traditions, particular those that were the product of centuries of Spanish-Filipino cultural interaction, were under threat and required protection, preservation, and promotion. An early expression of this cultural nationalist ideal was the founding of the Philippine Conservatory of Music in 1916. Jazz was not part of the curriculum.

It is within this context of upper-class resistance to hybrid music with foreign cultural elements that the modern dance music of Filipino foxtrots and one-steps became muted in 
Illustration 5 Modern jazz music was also regularly associated with noise, as evidenced by this advertisement for a medicine to combat headaches. Published in periodical D'Orient, Netherlands East Indies, 1936

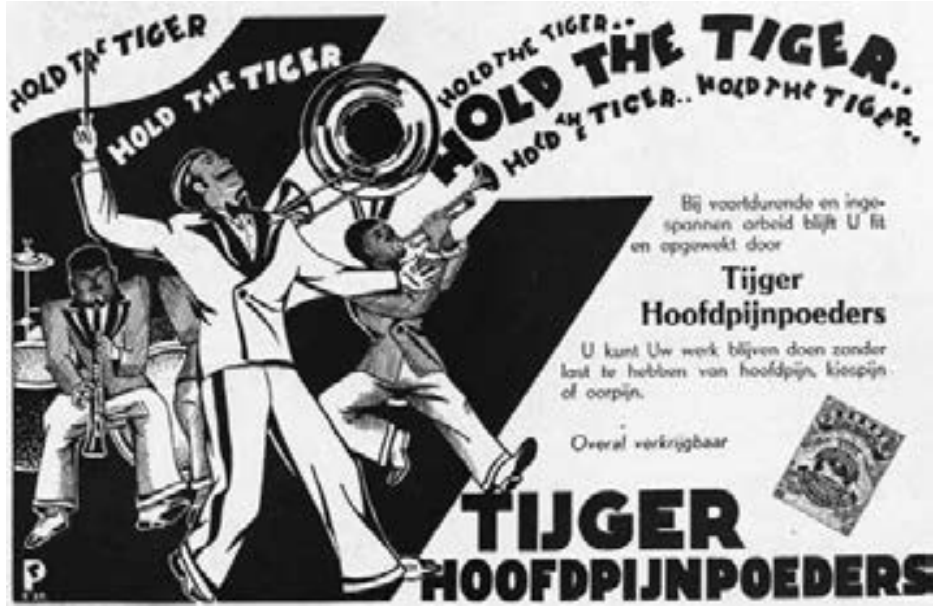

KITLV collection

Philippine historiography. Likewise, Luis Borromeo, as selfproclaimed Filipino King of Jazz, occupies an ambiguous position within Philippine musical culture and history. His name is remembered only in association with low-brow foreign music (jazz) and 'vulgar' vaudeville. For similar reasons Miss Riboet holds a comparable position in Indonesian cultural historiography.

The Japanese control over large parts of Southeast Asia from December 1941 into 1945 meant a break in the cultural hybridization and commercialization of music. Japanese cultural policies were largely anti-Western and the media was censored to serve Japanese war propaganda. Jazz became highly suspicious music due to its association with American popular culture. And, due to the breakdown of international commercial shipping, the vibrant local recording music industry and scene came to a virtual standstill. 


\section{Box 1.1 Phonographic noise}

During the Jazz Age, the urban soundscape changed into a cacophony of sounds from street vendors, automobiles and also gramophones. Gramophone technology was introduced in Southeast Asia at the beginning of the twentieth century. In the 1910s, this new audio technology was very much a novelty to most Southeast

\section{Illustration 6 Eurasian Malay opera actor, playwright, director,} singer and popular recording artist, P.W.F. Cramer, accompanied by a Malay opera leading lady (sri panggung) from Betawi (present-day Jakarta), standing next to a phonograph equipped with a giant horn, c. 1912

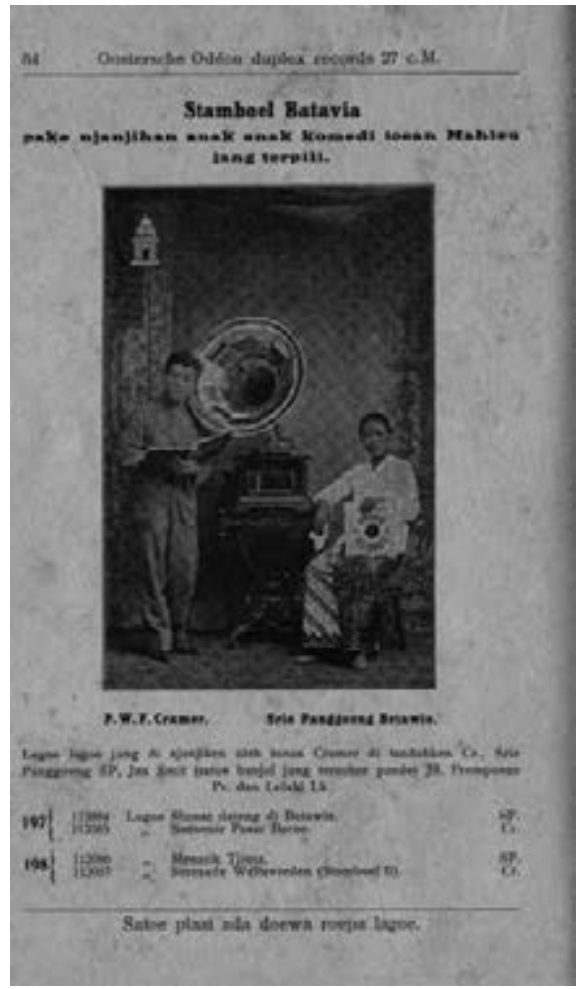

Odeon record catalogue, c. 1912

By courtesy of Jaap Erkelens 
Asians and restricted to the happy few. In Indonesia, itinerant 'musicians' carried small, portable gramophones around, playing Javanese and Malay songs for a small fee. By the 1920s, the gramophone had become a more widespread consumer item among the upper and upcoming middle class. Payment in instalments put the equipment within reach of more music fans. The gramophone was more than a medium to enjoy music, as expensive models were sold as pieces of furniture. A gramophone was reported among items of a Javanese dowry and many a native office clerk had this token of wealth, upward mobility, and modernity in his home.

In the 1920s, and increasingly so in the early 1930s, local newspapers in Southeast Asia started to report on 'nuisance,',noise' or 'gramophone nerves'. Electrically amplified models that were much louder than mechanically driven devices were the culprits. Music radiated in all directions, day and night, disturbing people's night rest and Muslim prayer. In 1932, in the town of Cimahi, West Java, a man was fined for playing records after ten o'clock in the evening. In 1934, the Singaporean authorities designed special legislation to deal with the noise of gramophones, pianolas (mechanical self-playing pianos) and other noise-producing devices. In 1936, a Chinese woman was penalized for having played her gramophone 'on the five-foot path' at her house in Singapore.

\section{Box 1.2 Dance halls}

The first dance halls in Southeast Asia appeared in the Philippines as early as 1902 in Caloocan, Rizal province, north of Manila and were later also found in Malaya. These social dance institutions almost exclusively catered to Filipino patrons. In 1910, John Canson, an American of Italian migrant origins and veteran of the PhilippineAmerican war, established the Santa Ana Road House in Makati, east of Manila. The Santa Ana cabaret, as it became to be known, would become one of the largest and sophisticated establishments in Southeast Asia and attracted both Filipinos and Americans. In the colonial Philippines, the Anglo-Saxon term dance hall was interchangeably used with the Castilian salon de baile and the 
French term cabaret. The latter was used for dance halls that offered performances as well as dancing. Social dancing, however, was the dance hall's core business. People danced to modern Afro-American dances, such as the one-step, foxtrot and also the Argentinian tango. The dance hall patrons, almost exclusively men, would choose one of the many female dancers employed by the hall and pay her a small fee in exchange for a fixed dancing time duration. This phenomenon was known as 'taxi dancing'. In the Philippines, 'taxi dancers' were known as bailerinas and they held a low social status. In the late 1910s, the Manila municipal authorities engaged in a moral crusade, leading to monitoring of dance halls and the prohibition of prostitution.

In the 1930s, dance halls and taxi dancers also appeared in the Straits Settlements and Kuala Lumpur. The Great World Amusement Park in Singapore had an open-air cabaret, where one could dance to live music with a dancing partner. Chinese associations threw so-called tea parties, which were, in fact, occasions for taxi dancing. Many of the dancers, including those in the Philippines, were hard-working women who supported extended families with their earnings from social dancing. However, a lot of these women had to endure moral disapproval and social stigmatization because of the thin line that existed between dancing and prostitution.

\section{Box 1.3 The modern woman}

Popular music and social dancing came together in another new social phenomenon in the 1920 s and 1930s: the modern woman. In the Philippines, several role models and stereotypes featured; from the despised but popular bailerina, flapper - the worldwide iconic modern girl of the Jazz Age, to the beauty queen. Flapper stood for the Americanized Filipina with bobbed hair, who smoked cigarettes and indulged in jazz dancing. Short stories in print, film stars, and advertisements for consumer items such as soap, shoes, and make-up, made the image of the flapper go global. Leading Malay opera singer-actresses took flapper and American actress Norma Talmadge, star of the silent movie, as a model for their own 
Illustration 7 Indonesian popular singer Dinah in modern dress and hair fashion, c. 1938. She engaged successfully in kroncong singing competitions in Singapore from 1937 onwards, recorded for HMV in Singapore, and appeared on radio in the Netherlands East Indies in 1940.

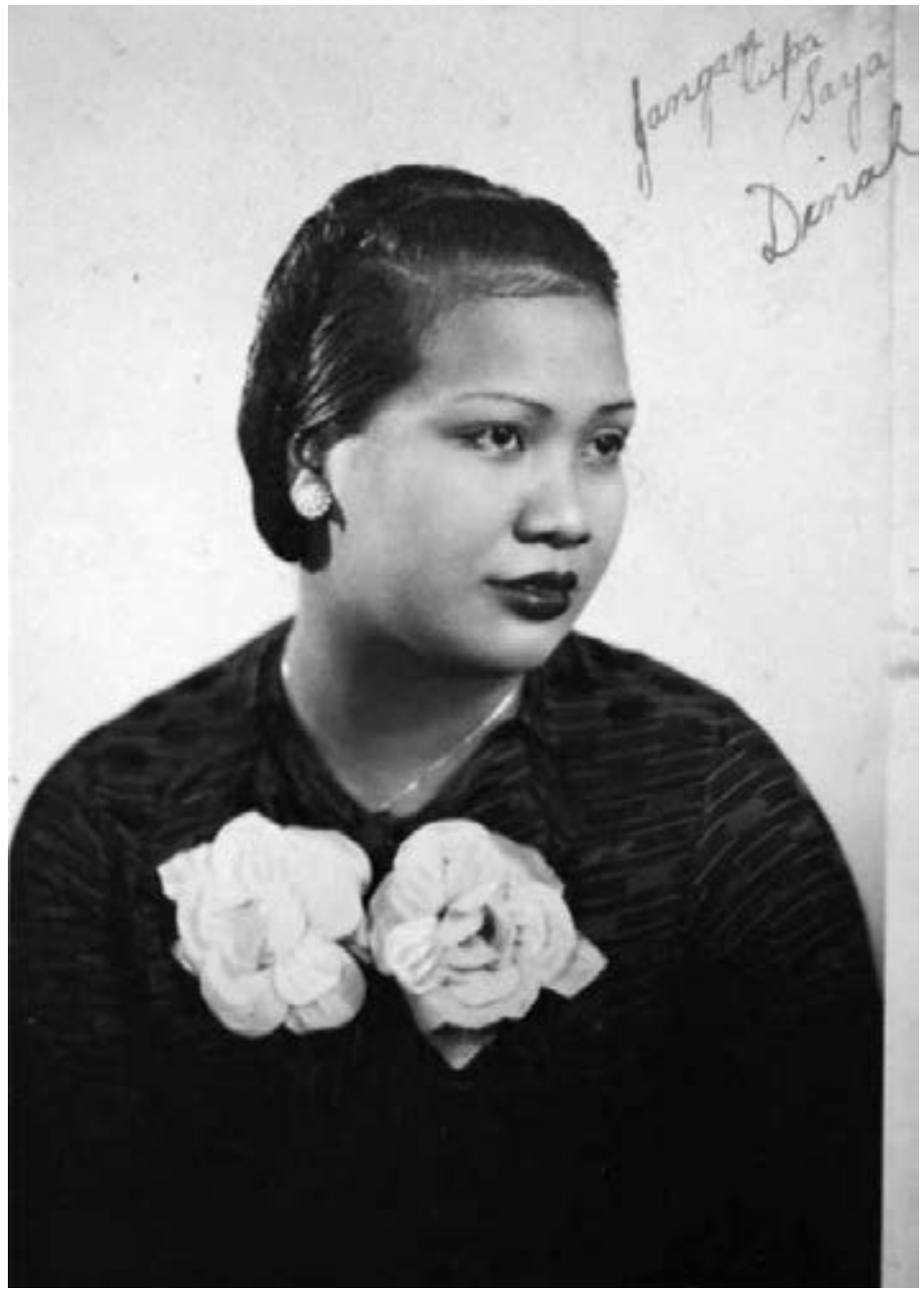

Postcard, Singapore, c. 1938

By courtesy of Marije Plomp 
dramatic acting. Consumerism and popular culture were explicitly linked for the first time in the late 1920s, after Malay opera stars appeared in advertisements promoting consumer items. In the Philippines, flappers created confusion about gender roles, as their lifestyle questioned femininity as well as masculinity. Flappers were associated with social deviance, including loose sexual behaviour, but were never placed in the same league of the bailerina, who, by definition, had a working-class background. What was at stake, here, was how to reconcile capitalist consumerism with that of Filipina motherhood and patriotism, a debate similar to that of the position of women in relation to nationalism in Indonesia and Burma. Public debates about modern women dominated by men gained currency from 1924 onwards. In the Philippines, the discussion dealt with aspects ranging from Christian morals, fashion, like hairstyle, and women's legal right to vote. There was also a great deal of fascination and curiosity with stardom as manifested by new female vaudevillians. In contrast to flappers, bailerinas and vaudevillians, Filipino beauty queens represented the elitist male ideal of the modern, virtuous, and patriotic Filipina, the wife and caretaker, the embodiment of the Philippine nation. 


\section{Jeans, Rock, and Electric Guitars, 1950s-mid-196os}

The Second World War led to a virtual standstill of the recording industry in Southeast Asia. In the late forties, the industry resumed business as usual. For example, in Singapore in May 1947, eighteen months after the Japanese capitulation, Pathé (known locally in Malay as 'Chap Ayam' or 'the chicken brand'), a subsidiary of the Anglo-American owned Columbia Graphophone Company, issued new record catalogues. Rival record company His Master's Voice, a subsidiary of the Anglo-American The Gramophone Company Ltd., followed suit. The two companies advertised for popular hybrid Malay and Chinese song repertoires typical of the pre-war period. No sign of musical innovation or a restructuring of the industry could be yet observed.

The following decades, the 1950s to 1960s, saw a succession of new developments in Southeast Asian popular music. This chapter addresses three salient trends in the relationship between popular music and society in this era: the emergence of youth culture, official moral indignation, and the beginnings of a local music industry.

Evidence on Thailand, Malaysia and Indonesia, points to a shift in the relationship between popular music and society in the mid-1950s. This was a global phenomenon. For Southeast Asia, the 1950 and 1960 s were turbulent decades marked by decolonization, nation-building, and political and economic instability. Many formerly colonized peoples felt disillusioned about democracy and the new leadership, were disenchanted with the failure to end the uneven distribution of wealth and unequal access to education, and felt frustrated about continuing economic dependency on the former colonial powers. Throughout the 1950s and 1960s, central governments met with regional rebellions and resistance from communist movements. The unfolding of the Cold War aggravated political tension and armed conflict within and 
between countries. To combat communism within and beyond its borders, the Philippines allied with its former colonizer the USA in 1950. Thailand's military regime followed in 1952. South Vietnam entered an anti-communist alliance with the Americans. In return, these U.S. allies received financial and military support. In the mid-1950s, Indonesian-American relations deteriorated. By 1957, as the Partai Komunis Indonesia turned into the biggest communist party in Southeast Asia, and President Sukarno's initial non-alignment policy began to move in the direction of China, the CIA covertly supported anti-communist forces in Indonesia. A similar scenario unfolded in Cambodia under Norodom Sihanouk, who was unable to maintain his position of non-alignment and was overthrown by a military regime that itself came to be challenged by a communist movement known as the Khmer Rouge.

In spite of a growing interest in the impact of the Cold War on politics, society, and culture in the region, the 1950s and early 1960 remain among the least studied periods in the cultural history of twentieth-century Southeast Asia. Contemporary newspapers, $78 \mathrm{rpm}$ shellac records from the $1950 \mathrm{os}$ and early 1960s, youth magazines, vinyl records, record catalogues, and record sleeves form a largely unearthed body of historical sources. Apart from sketchy references to Singapore amusement parks in the 1950s, we know little of the venues where music was performed, how people danced, and where they hung out. Music lovers and dance fans, musicians, business entrepreneurs, recording engineers, and producers of a newly emerging youth culture remain largely mute. What we do know is that, in this period, rock and roll music hit Southeast Asian coasts, a musical style that captivated singers, musicians, and a group of new fans.

\section{Youth culture}

A fascinating development that became visible around and particularly after the mid-1950s is a music- related youth culture across Southeast Asia. Of course, the consumption-oriented 
Illustration 8 Brilliantine was an indispensable product for men in the 1950s. It kept the hair well-groomed and gave it the shine.

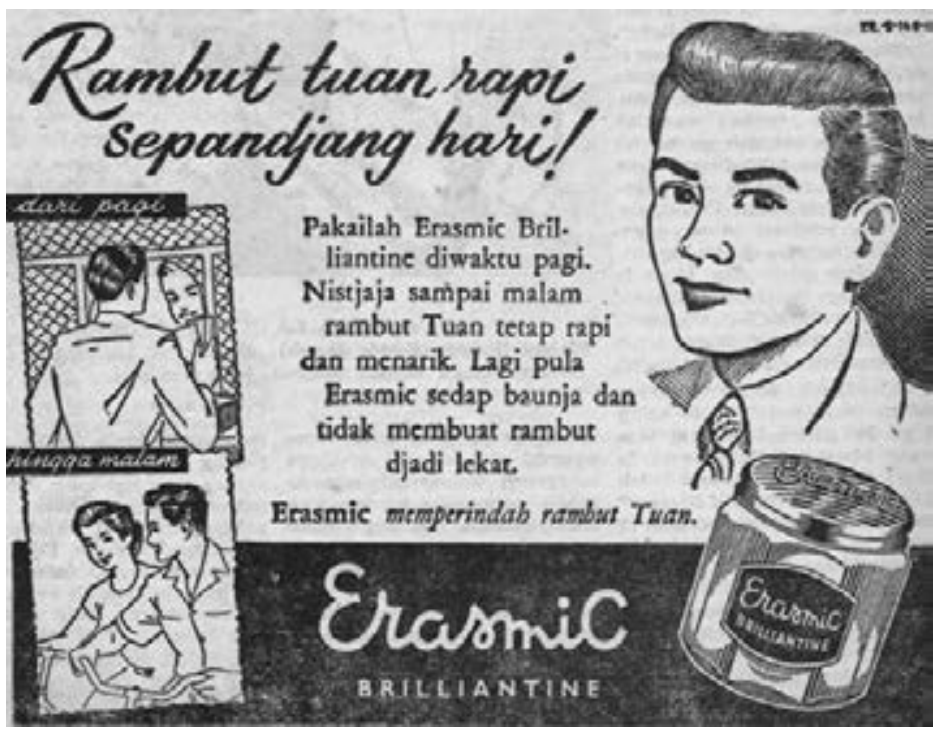

Indonesian magazine Waktu, 1956

KITLV collection

modern girl had appeared in the 1930s; teenagers had already discovered 'the talkies', and they danced to modern music in amusement parks in Singapore, in dance halls across the Philippines and at fairs in Java. In the mid-1950s, however, youngsters became far more visible and outspoken as fans and consumers of and contributors to a popular culture in which music was an important social and cultural marker. Of the new music styles introduced in the region, rock and roll and Latin American and Caribbean music, like the cha-cha and calypso, proved the most suitable to articulate new music and lifestyle.

Teenagers in Southeast Asia, as in the USA, Europe, and elsewhere, were seeking new identities and new ways of expression. Aided by the foreign film industry and visual images of distinctly 
American clothing, rock and roll was more than music. It presented a lifestyle including tight trousers (the iconic blue jeans), typical hairdo, and other attributes like motor bikes. Movies like Rock Around the Clock (1956), Rock Rock Rock (1956), and Don't Knock the Rock (1957), the first two featuring American rock and roll artist Bill Haley and his band, were screened in all the major cities' theatres. In Singapore, Jakarta, and Bandung these movies were box office records. The musical package of youth culture that comprised film, the sound of amplified guitars, jukeboxes, clothing - lifestyle, in short - offered youngsters distraction, a new identity, and a new sense of community.

Snapshots of this new youth culture can be traced in contemporary newspapers reporting, often in a paternalistic and reactionary mood, on youths. Teenagers dressed in blue jeans often hang around collectively in distinct localities: specific residential neighbourhoods, schools, or around newly emerging shopping centres, the precursors of the modern malls. In Singapore, the Shaw brothers film company sponsored rock and roll musical performances and dance contests. The amusement parks did the same, always ready to catch up with the newest and commercially promising fads, from bathing suit contests to rock and roll dance competitions.

Rock and roll transcended the local. In 1956, the Happy World amusement park in Singapore hosted Rock-Around-The-World, a ten-night show featuring American, Filipino, and Hawaiian 'rollers'. The first rock and roll dance contest of the Far East was held in Bangkok's Lumpini Hall in April 1957. The winning couple were Suzy Lye and Thoo Thean Soon, age 16 and 19, respectively, peranakan Chinese from Ipoh, Federation of Malaya. Under the eyes of the king of Siam, who was among the spectators, they had to compete with contenders from Singapore, Penang, and Thailand. The couple declined an offer to perform in nightclubs in Thailand, as they were still attending school and had no intention to become professionals.

Evidence from Indonesia, Malaya, Singapore, the Philippines, and Thailand suggests that teenage music fans originated from 
Illustration 9 New American dances were tried on the dance floor at social gatherings such as at this Bandung high school party, c. 1957.

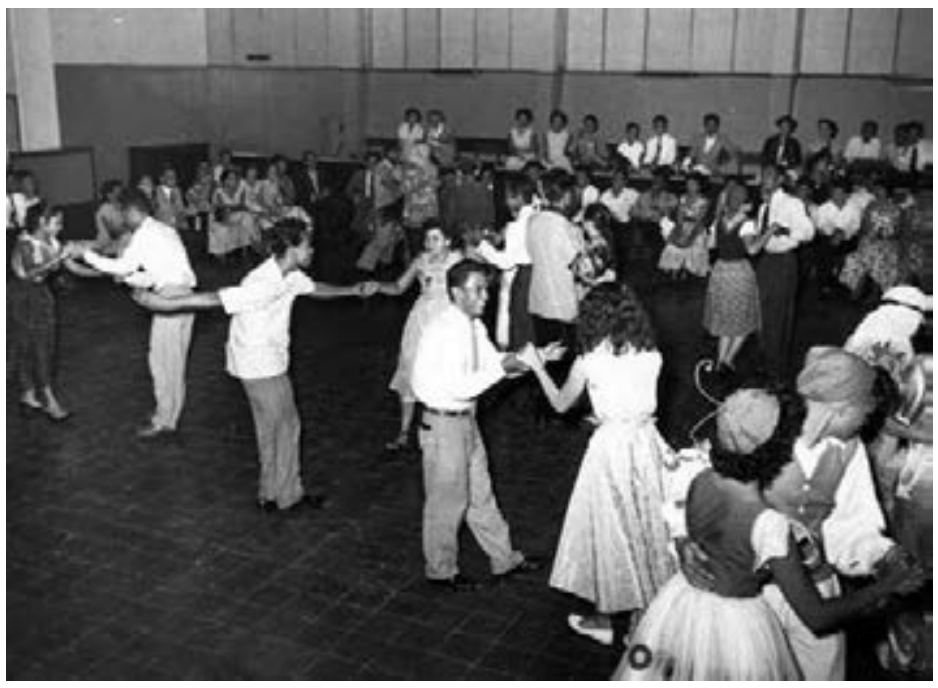

By courtesy of Marije Plomp

urban middle-class to upper-class environments. They could afford to buy gramophone records, a radio set, some electric guitars, and travel to distant places for dancing contests. In short, they had the financial means to engage in both the consumption and production of popular music. For example, the aforementioned dance contest winners Suzy Lye and Thoo Thean Soon originated from locally rooted Chinese business families and attended Anglo-Chinese schools. The founder of the Philippine rock and roll band $\mathrm{RJ}$ and the Riots, Ramon Jacinto, came from an affluent family. His father was a leading Southeast Asian steel industrialist and among Metro Manila's wealthy businessmen. An accessible way of listening and dancing to recorded music was the jukebox. In the Philippines, this device was found in bars, restaurants, and other public places. By paying only ten centavos, people could select a song and listen to it. 
Articles and news items in the print press make clear that rock and roll youth culture represented a form of resistance against increasing authoritarian, parental or/and official, control. One aspect of the new emerging youth culture, gang formation, was of particular interest, not only to the print press, but to the authorities as well. In Southeast Asia's major cities, youth gangs proliferated; gang members engaged in petty crime and violence in schools, shopping areas or specific urban neighbourhoods. Gangs not necessarily identified with rock and roll. But, in many cases, gang members were found sporting the new look of blue jeans, making it almost equivalent to juvenile delinquents' fashion, at least in the official eye.

\section{Moral indignation}

The association of youth fan culture with criminality was part of the moral anxiety with modern youth culture in a broader sense, which swept the region from the mid-1950s onwards. Officials and reactionary citizens across the region questioned the blessings of Westernization and modernity. This situation resembled and refuelled old debates since the 193 os on the role of popular music culture in national culture and in nation-building. Between 1956 and 1957, discontent developed within Thai, Malaysian, Singaporean, and Indonesian government circles about what was seen as the excrescences of rock and roll: juvenile delinquency, improper relations between the sexes outside marriage, offensive clothing and indecent hair dress. Politically innocent rock and roll youth culture became politically charged and socially ostracized.

In Singapore, the famous, but by then veteran, composer Zubir Said, publicly condemned foreign popular music as being detrimental to the Malay language and culture. His position is rather ironic as he himself was rooted in the pre-war hybrid world of modern popular Malay music that had absorbed many foreign musical influences from jazz to rumba. Moreover, Said had since the early 1930 s worked as talent scout and musical 
director for the Singapore office of the recording company HMV. Closely collaborating with HMV he had been pioneering local popular music, and had actively contributed to producing a new hybrid popular culture that in the 1950s had become accepted as part of Malay culture. Zubir Said by no means stood alone. A Malay cultural organization appealed to the Singapore and Malay Federation governments to ban all rock and roll movies, songs, and dances in order to protect Malay culture from demise.

Between 1957 and 1959, the authorities of the Malay Federation, Singapore, and Indonesia looked to each other as how to handle what was perceived as a common cultural threat known as rock and roll. In February 1957, Indonesia's national radio station, Radio Republik Indonesia, banned rock and roll and 'similar music' from all its stations, in tandem with President Sukarno's anti-Western rhetoric and cultural nationalism. Islamic political party Masyumi independently opposed to rock and roll film screenings. The Jakarta municipal authorities banned rock and roll dancing from public spaces. By the early 1960s, resistance to and even rejection of American pop culture by political elites was the rule rather than the exception in most of Southeast Asia. This included even those countries, such as Thailand and South Vietnam, that allied with the U.S. and actively supported their patron to combat communism domestically and regionally. In various degrees, the governments of Burma, Malaya, Singapore, and Thailand took what proved to be token measures to curb the allegedly debasing influence of blue jeans and rock and roll. Opposition morphed into government action censoring movies, halting rock and roll music broadcasts, prohibiting musical performances, bands, and sometimes types of clothing. In Saigon, for instance, blue jeans were banned for youngsters.

\section{Local industry}

Another feature of the 1950 s is the development of a music industry owned and managed by locals who catered to a local 
audience. Although the histories of these record companies, the people behind them, and their economic, cultural, and social significance remain conspicuously sketchy, we can see that what was an infant industry in the 1950s expanded and professionalized in the late 196os. The face of the region's recording industry changed significantly, marking economic and cultural 'decolonization' of the music industry. In the early 1950s, entrepreneurial-minded and music-loving locals in Burma, the Philippines, and Indonesia, established recording companies and studios, followed by pressing plants. These ventures were no longer owned and managed by one of the major foreign companies that had monopolized the industry before and shortly after the Second World War. Local entrepreneurs had moved in. The exception was Singapore; the Lion's Gate city remained a stronghold for international companies within the region.

The local record companies, and later also radio stations, shared with the foreign companies a 'discovery' of 'youth' as a new market. Yet in contrast to the foreign-owned record companies, the newly established local record companies had to deal with national markets and the social-political issue of nation-state building. In some cases, as for example in Indonesia, an ambiguous relationship between commerce, cultural nationalism and nation-building developed as a result as the examples of the record companies Irama and Lokananta illustrate.

Lacking the technical skills and recording equipment, some of these early local companies continued to rely on assistance from the foreign companies. For instance, the Indonesian record company Irama, established in 1951, hired an experienced foreign recording engineer and relied for its production process on the Dutch company Philips. As for music, Irama continued the pre-war pattern of promoting both 'national music styles' such as kroncong and Melayu, and, to a lesser extent, Western songs (lagu Barat). It rarely produced jazzy music. Religious and Indo-Arab music, like qasidah, and, from the late 1950s, the new genre of rock and roll, are conspicuously lacking in Irama's 
repertoire, indicating a conservative policy along mild nationalist lines. The company actively promoted modern renditions of regional or ethnic music (lagu-lagu daerah). This repertoire included folk music in popular Western music style arrangements performed with modern amplified instruments. The Jakarta-based Irama studio provided its talented crew to work music for theatre, cinema, and broadcasting for national radio. Its position as recording company was only challenged from 1957 onwards with the establishment of the state-owned record company Lokananta in Surakarta, Central Java. This company also focused heavily on recording regional music, promoting Indonesian cultural diversity. Indonesia's mounting economic and political crisis, starting around 1957, is likely to have sealed Irama's fate somewhere in the 1960 s.

\section{Beat goes local}

What was set into motion in the second half of the 1950s, spilled seamlessly into the 1960s: moral concerns about youth culture and music as debasing morality and patriotism. In 1960, the Singapore authorities banned rock and roll by censoring private radio broadcasting and movies. The military regime in Burma rejected Western-style compositions. Here, the popular music industry deteriorated after the authorities imposed an import and export stop, followed by radio broadcasting censorship in the late 1960s. In Indonesia, further steps were taken to protect national culture in 1963, when a Presidential Decision forbade any public airing of rock and roll. In 1964, police operations were undertaken in the provincial city of West Java, Bandung, with the aim of publicly burning Elvis Presley records and 'disciplining' young men with shaggy, Beatles-style haircuts. At the same time, the rules of these prohibitions were neither clear-cut, nor consistently applied. Sometimes, musicians performing the forbidden styles appeared as guest stars at state-sponsored live events, or as contestants in the national public radio song contest. 
In their attempts to assert a distinct national cultural identity that was refined in modernity, yet rooted in indigenous traditions the Singaporean and Malaysian nation states followed a path of repressive policies similar to that in neighbouring Indonesia. To the older generation of conservative political leaders, law makers, local artists and government officials the 'beat music' youth culture of the 196os represented everything the post-colonial Singaporean and Malaysian nation-building project was against. As a cultural counter to 'Westernization' expressed in forms of popular culture such as pop music, gramophone records, radio broadcasts, and cinema, Malaysian popular singer P. Ramlee, among others, romanticized Malay rural life in his songs and movies. But by the mid-196os, Ramlee engaged in a musically and commercially rear-guard action. Attempting to compete with the new popular rock and beat music he condemned, he paradoxically appropriated modern Western-style dance music in the form of the twist. In 1965, he released 'Twist Malaysia', a patriotic song dedicated to the independent Malay nation and its people.

In contrast to the repressive policies of other countries in the region, Cambodia followed a different trajectory. By no means less authoritarian than other regimes in the region, Norodom Sihanouk, in power from 1955 to 1970, allowed space for rock, pop, and other Western music to develop. By the 196os, Cambodian musicians had fruitfully mixed Western rock and cha-cha with local music, and produced a hybrid sound and music industry of their own. The Khmer Rouge, in power from 1975 to 1979, cracked down on what they saw as Western decadence and urban perversity, including the local popular music industry. Apart from the deliberate destruction of vinyl records and cassettes, a generation of pop stars that had emerged in the 1950s and 1960s, including many female stars, were literally wiped out by the new regime.

In most of the countries, however, official suppression was of limited effect. Musicians operated relatively autonomously from government interference. This is testified in one striking feature of popular music in the early 1960 s that continues to be popular to this very day: cover bands. These bands consisted 
of fans-turned-amateur-musicians imitating rock and roll and British beat music. Bands emerged that, in turn, amassed their own local fans and followers. Adaptation of this new culture of dress, music, and dance by youngsters should not be understood as simple mimicry or as proof of successful Anglo-American cultural imperialism. Already during the Jazz Age, Southeast Asians practised what has been and still is universally inherent to processes of musical production: adaptation, imitation, and innovation. One of the tested steps away from the original was to replace foreign lyrics with the local vernacular. Some of these music lovers would go beyond imitation. They transformed the sources of origin into distinctively new styles by incorporating local folk melodies, lyrics in the vernacular, local tunings and rhythms, and by using local instruments.

In Singapore, Ramlee's attempt to catch up with the times failed; a wave of cover beat bands, inspired by the Beatles and the Rolling Stones, had taken over. These new bands developed a genre known as 'Pop Yeh Yeh' after the Beatles' song line 'She loves you yeh, yeh, yeh'. Another parallel development was the emergence of Malay bands known as 'lively guitar bands' (kugiran). The musicians were inspired by beat music, but created their own original compositions with Malay lyrics. In Burma, a cover band tradition matured into a respected popular music genre known as copy tachin. In Thailand, the genre known as 'Wong Shadow' emerged and moved away from its original source of inspiration, the British guitar band the Shadows. In Thailand, as well as in Cambodia, the Shadows' distinct amplified tremolo guitar sound rather than the smooth vocal style of their lead singer Cliff Richard appealed to the youth (see box 3 on the tremolo guitar). The sound of Wong Shadow was hybrid and rhythmic, and its instrumentation likewise eclectic. We find Latin-style rhythms, such as the cha-cha and rumba, performed on Latin percussive instruments and Western drum kits, with Thai percussive ornamentations, including gongs and drums, indicating this was music for modern dancing. Most songs followed Western guitar chord progressions. In some cases, Thai rhythmic styles formed 
the song's basis. There are instrumental pieces, some with horn sections inspired by African-American soul and funk. Apart from the tremolo guitar, the Hammond organ often also played a significant melodic role.

Some of the cover bands made it as professionals. Others, for example in Thailand, went through the process from covering songs to creating original songs, performing, recording on gramophone, and playing in radio studios. This period in Thai history is generally regarded as the formative years of modern popular music in Thailand. Peasants flocked to the cities to seek economic and political security in the wake of pressures on land and political instability in rural areas. New genres such as pleeng luk thung ('Thai country music') emerged, in which Western dance rhythms and instrumentation were fused with ethnic, particularly Isan, folk melodies and singing styles. To be accepted by the audience as a legitimate luk thung singer, a rural background was crucial. In their songs, these artists addressed the hardships of urban life, poverty, and discrimination in contrast to peaceful village life. The irony was that in terms of record labels, recording studios, and radio broadcast stations Bangkok was the centre of this creative industry. It was in this city that pleeng luk thung production thrived (see chapter 3 for similar paradoxes). In the Philippines, a similar development of mimicry took place, but, unlike the Thai case, no new genre developed that was stylistically different from the original source of AngloAmerican rock and roll. For example, RJ and the Riots, founded in 1960 in Manila, idolized the American band The Ventures, and modelled their own band on its instrumental rock and roll.

In the late 1960 s, the fashion of greased quiffs and tight pants made way for long hair and miniskirts. Popular music was also on the move again. New musical genres, bands, and their fans dawned in 1968, the year that marked the worldwide introduction of the audio cassette. This new and relatively inexpensive audio technology would open up new opportunities for local artists, musical genres, and business entrepreneurs that would manifest itself in a cassette revolution and cassette culture in the $1970 \mathrm{~s}$. 


\section{Box 2.1 Gangs}

In 1957, the Indonesian authorities in the cities of Jakarta, Bandung, and Medan ordered youths, known by the generic name of 'cross boys', to report with the local military. These teenage boys were said to engage in 'wrongdoings', including wearing improper blue jeans and driving motorcycles on which they had written indecent texts. In some cases, as in Medan, youngsters engaged in illegal cinema ticket trade and violence. In face of policing by the local authorities and to avoid interference, youths in Jakarta claimed to represent and hold membership in officially registered football associations. A connection between gangs, juvenile delinquency, and wearing jeans was also found in Bangkok, Singapore, Penang, and Saigon. The adjacent provinces of Manila were notorious for gangs of teenagers, Cavite province being a hot spot. The Filipino gangs were of a different order compared to Indonesia's cross boys. They were often linked to violent political strife, resulting in kidnappings and killings. In the early 1960 s, some youth gangs in Singapore, Penang, and the Federation of Malaya, believed to be connected to Chinese secret societies, gained a criminal reputation. In Penang, the police force issued pamphlets advising parents to prevent their children joining gangs. As an alternative for membership of a gang, the Singaporean authorities sponsored youth clubs that offered 'health-giving recreation'. In 1960 and 1961, the Singaporean and Penang authorities embarked on a crackdown on youth gangscum-juvenile delinquents and the secret societies by raiding hide outs.

\section{Box 2.2 Blue Jeans}

Hidupan Barat jaman sekarang lagi perempuan pada pakai celana Model kuno jauh dibuang Jika tidak ... aah ... ketinggalan jaman.

The Western lifestyle of today makes ladies wearing trousers as well Old-fashioned models are thrown far away If not ... aah ... you are outdated 
Celana Yankee aksi dansa dancing

Sradak-sruduk seperti babi cari ubi

Celana Yankee doyan bugi-wugi

Kosrat-kosret bah kucing mabuk terasi.

Yankee trousers, doing the modern dance

Like a pig rooting about for cassava

Yankee trousers, enjoying the boogie-woogie

Like a cat intoxicated by shrimp paste.

'Tjelana Djengki'. Artists: Ati and B. Pessulima. Composer Henny Gatot. Irama, c. 1953.

Recordings artists of the first independent Indonesian record label, Irama, performed this song, which was stylistically cast in the recently arrived jazz bop style, a genre never popular beyond a tiny group of modern jazz fans. Released around 1953, before the advent of rock and roll, the song sardonically referred to the new fashion of jeans trousers, and its growing appeal among females. This song was still innocent compared to later moral anxieties with modernity and foreign cultural influence. In 1957, the extreme case of a young girl was recorded in Aceh, North Sumatra. She was flogged by two boys for wearing tight and 'indecent' tjelana Djengki ('Yankee trousers').

\section{Box 2.3 Tremolo guitar}

The guitar found its way to Southeast Asia in the footsteps of European traders and missionaries in the sixteenth and seventeenth centuries. Following the introduction of the Hawaiian acoustic and electric lap steel guitar in the 1920s and 1930s, the next guitar that left its imprint on Southeast Asian popular music was the electric amplified tremolo guitar. Although the vibrato guitar system, generally known as 'tremolo', was already in existence in the 1930s, it came widely into vogue among American musicians in the 1950s. This was followed by British and Southeast Asian guitar adepts in the 1960s. A twanging sound effect is achieved by manipulating a lever 


\section{Illustration 10 Fashion-conscious Bandung youth sporting tight}

jeans, C. 1957

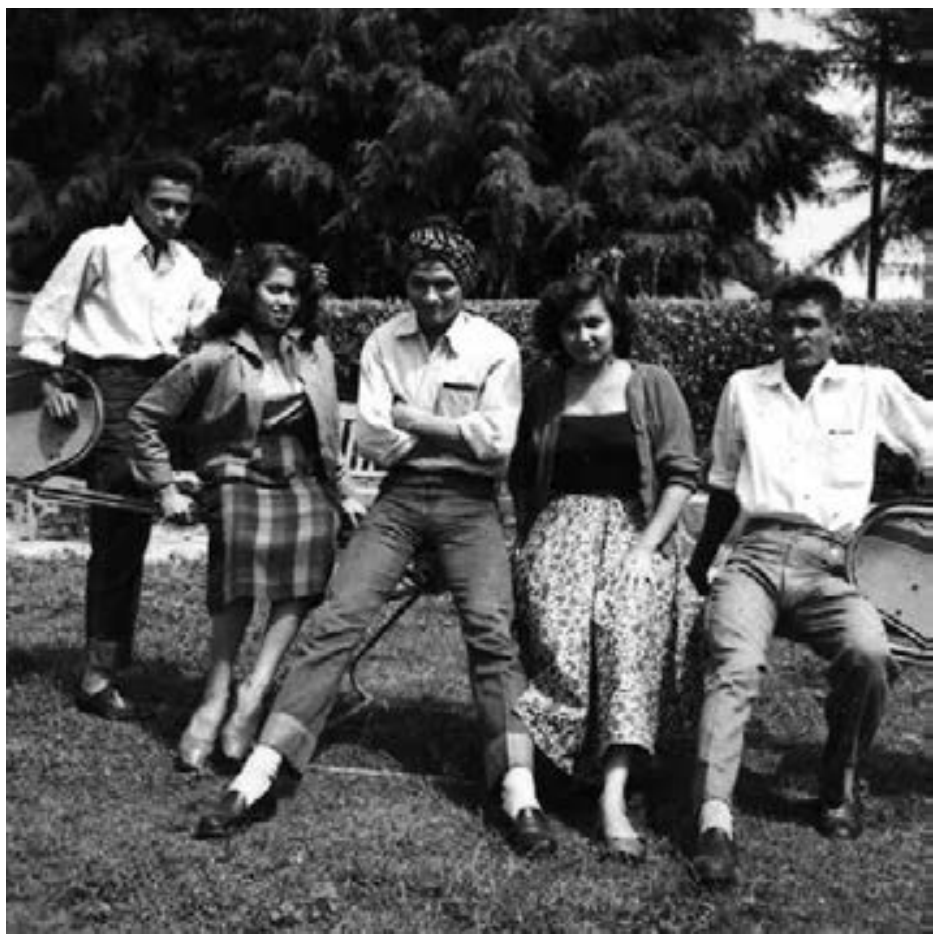

By courtesy of Marije Plomp

attached to the bridge at the tail of the electric amplified guitar. The penetrating tremolo sound is perfect for emphasizing repetitive melodic lines and for soloing. Although different guitar brands used alternate versions of the same principle, it was the American guitar company Fender that is probably best known for its tremolo models. The tremolo guitar and its sound gained worldwide popularity through bands like the Shadows and The Ventures, who, while doing their synchronized dance moves, used this guitar on stage producing a distinct electric amplified twang sound effect. 



\section{The Ethnic Modern, 1970s-199os}

\section{Modern music for the Muslim Malay masses}

The 1970s-1980s was a time of both uncertainties and new opportunities. It was an era in which the new-born nation states of Southeast Asia boldly took the road of Western-styled development with economic successes that were nothing short of spectacular. The new-found prosperity was well reflected in the massive growth of metropoles such as Jakarta, Kuala Lumpur, or Bangkok, which now drew hundreds of thousands of newcomers from both the nearby countryside and often remote islands, resulting in a hotchpotch of cultures, ethnic affiliations, and a variety of lifestyles in the city's neighbourhoods. Also, the 1970s, and continuing in the 1980 s, saw the resurfacing of religion in the public sphere, with especially the Islamist movement in much of Muslim Southeast Asia rapidly gaining ground. As a result, Southeast Asians were increasingly (re-)embedded in alternative trajectories of globalization, the West no longer serving as exclusive role model on how to be modern.

This was also an era marked by a rapid coming and going of new musical technologies, genres, and audiences. In terms of novel technologies, these were the years of small, cheap, and oftentimes democratizing media, such as samplers, and especially the cassette player, allowing, respectively, for an incorporation of traditional sounds into modern pop genres and easy and quick multiplication of recorded music without the need for heavy investment by large record companies. Such smaller media similarly allowed for commercial release of genres that hitherto had long been ignored or deemed commercially less viable by the industry, including new hybrid genres of religious and ethnic music. Such genres would soon become popular among audiences in Southeast Asia's metropoles. Having left their home villages and root cultures behind, many still seemed to struggle with adapting to modern city life and the values it came with. The rise 
of a modern Islamic musical genre called nasyid - songs with Islamic content and the implicit aim to convey a moral message and spiritual advice (dakwah) in an everyday context - may help to illustrate this phenomenon.

Islamic music has been recorded and consumed by a mass audience ever since the advent of the recording industry, but it was only towards the end of the 196os that companies began to realize its full potential. They started to target the vast Muslim Malay market in Southeast Asia. Much inspiration was found in gambus, a musical genre rooted in the Arab-Indonesian community and available on record since at least the 1930s. But gambus comes with the disadvantage that it was mostly sung to in the Arabic language. And although Southeast Asian Muslims were well acquainted with Arabic through their religious practices, it was not the language they used for daily communication. Towards the 1960s, Muslim Malay performers in Indonesia and the newborn nation states of Malaysia and Singapore started experimenting with gambus using the Malay language. This resulted in a hybrid genre variously branded as nasyid (padang pasir), qasidah moderen, orkes dakwah, or orkes padang pasir. The latter two terms refer to the gambus-style 'desert rhythms': the musical beat that invoked a Middle Eastern, and thus, Islamic mood.

It is Ahmad Baqi (1922-1999) from Medan who is generally considered the 'Master of Desert Rhythm'. He was an early pioneer of nasyid. With Baqi, a modern practice of Islamic music surfaced that addressed the needs and aspirations of a contemporary Malay Muslim audience that increasingly had become aware of itself. Baqi's father, a religious teacher in the Deli Sultanate on Sumatra's east coast, wanted his son to follow in his footsteps, but Baqi preferred playing music on the violin and other string instruments. His religious background, however, continued to inspire him as a composer; it is believed that he composed over a thousand songs. In 1956, Baqi teamed up with an Egyptian group led by the musician Mahmud Ibrahim. It enabled him to meet with some of the religious teachers of the prestigious 
Al-Azhar University in Cairo. On that occasion, he was given a 78-stringed gannuni zither, which he managed to master in only a short time, or so the story goes. Over time, Baqi performed with a succession of musicians and bands. He joined forces with prolific lead vocalists, such as Rokiah Zain, Asmidar Darwis, and especially Hajah Asiah Jamil. Asiah, who had already gained wide popularity during the late 1960 s, not only recorded with Baqi, but across a range of Islamic music styles, including gambus, qasidah, and nasyid moderen. In the late 1960s, Asiah and others joined the Padang Pasir Orchestra that Baqi had launched to provide his students with a musical home. This Orkes Nur El-Suraya, or just El-Suraya, performed at hotels in and around the Medan area, but also at marriage ceremonies and during Islamic festive occasions.

El-Suraya's first and best remembered commercially released song 'Selimut Putih' ('White Linen') was an arrangement by Baqi himself with lyrics by Ustaz Haji Mohammad Ghazali Hasan. It was created in 1968, but first released on record in Malaysia around 1970, as a two-song mini-album on ABC Records (the other side had 'Usah diingat' or 'The Necessity to Remember'). On this occasion, it was Atiqah Rahman's chilly vocals that caught the imagination of many a Malay Muslim listener and the song soon became iconic. The release of this mini-album proved how fluid the market for Melayu-inspired music still was, with records being equally and simultaneously consumed in Singapore, Malaysia, and Indonesia. It also demonstrated that an almost eschatological message - the song tells the story of a human being upon her or his death, who finally meets with archangel Jibrail - could have commercial value.

Although 'White Linen' seemed to counter the optimist tale of progress and secular modernity propagated by the post-colonial state, Baqi and El-Suraya were asked by the local Malaysian authorities to join the campaign for the Federal Land Development Authority scheme (FELDA). This programme was aimed at relieving poverty among the Malay population through modernization. To be successful, these endeavours needed religious 
and especially popular justification and that is where El-Suraya came in. Through their music, the musicians morally addressed the Malay rural poor who were brought en masse under the management of FELDA. At the same time, El-Suraya's Islamic nasyid music counterbalanced the growing popularity of the 'foreign' pop yeh yeh among Malay youth.

But there was resistance to this Islamic pop music too, from both state and religious circles. In September 1974, newspapers announced that Radio Televisi Malaysia had decided to officially ban 'White Linen' (together with 62 other songs, including the 'obscene' 'Screw You' by Elton John), and declare it haram, forbidden by Islamic law. The newspapers quoted disappointed female listeners who wanted to know where they would still be able to purchase the record, as it was no longer in stock. They stated that the music touched them deeply and that the lyrics contributed to religious awareness among their families. Only a week later, the newspaper announced that, after an intervention by the Minister of Information, fans of 'the song with a religious and desert rhythm character' could rejoice as Radio Televisi Malaysia had started playing 'White Linen' again.

This story of Ahmad Baqi, El-Suraya and the song 'White Linen' features some of the tendencies that were manifest during this particular era: the rise of formerly obscure musical genres through ethnic and/or cultural religious framing, a musical message that worked with the state's ideas of modernity and progress as often as it ran contrary to such a message, and the introduction of new and cheap audio technologies that made it possible for music lovers to play the music they held most dear, whenever and wherever they wanted.

\section{Pop history, as we know it}

Another feature highlighted in the story of El-Suraya is the tremendous speed by which new labels and genres came and went throughout the 1970 a and early 1980 s. This was not least 
due to the hunger of both the industry and audiences for new musics that were considered at once 'modern', hip, and fashionable, and yet somehow distinctive from what other artists in Western and especially neighbouring countries had been doing. This was achieved by mixing local music or music styles with foreign sounds. The recording industry was thus quite inventive; at times, social and cultural values were transgressed during the creative process. But the very same industry could be utterly conservative as well; too much musical frolicking would lead to low sale numbers.

This ambiguous attitude of the industry explains why, upon entering the 1970s, rock and roll and Western pop continued to be by far the most dominant genres in the larger part of Southeast Asia, in spite of the often-heard demand for a decolonizing of the cultural sphere. It is a dominant culture that is epitomized by the Bandung-based youth magazine Aktuil (1967-1986). Aktuil captured the spirit of the rock era, its creative slang and blue jeans fashion in an experimental and, at times, entertaining way. But this somewhat belated 1970s, middle-class consumption of 'rock and revolt' is also formative, as pop scholar Emma Baulch has argued, for much of Indonesia's musical journalism and criticism today, defining rock and its rebellious image as more 'real' and 'authentic' than other genres.

However, not all musical developments of that era equally fit such 'middle-class myth making'. The early 1970 s also saw other, less prosaic, appropriations of globally popular trends, examples including the popularity of 'blaxploitation' music and movies such as Shaft (1971) or Superfly (1972), in which black artists had the lead and stereotypically featured as hero, warrior, or the cool bad guy. Another worldwide and simultaneously Southeast Asian phenomenon was the fame of, for example, the Charlie Angels TV series (locally rendered into Indonesian action flicks such as CewekJagoan, or 'Deadly Angels', or 1981's Mystics in Bali, with almost identical content). 1970s Southeast Asia, like most other regions in the world, saw young people also dancing to funk, soul, and especially disco (see box on 'disco'). 
During this era, Indonesian President Suharto's New Order regime broke with his predecessor Sukarno's condemnation of Western pop as being perverse and imperialist. Much like what happened during the Malaysian New Economic Policy, a financial restructuring of the Malaysian nation that took place from the early 1970s onwards, Suharto primarily invested in Western-style development. These were the formative years of what today is still called pop Indonesia. This term refers to a musical industry label of all sorts, hinting at Anglo-American-inspired popular music (mostly love ballads using vocal harmony), sung in English or, more often, in the national language. Pop Indonesia, with artists such as Titiek Puspa, Andi Meriem, Rafika Duri, Emilia Contessa, or Broery Marantika, stood for modern amplified music, using Western instruments, mostly played at indoor venues. This kind of music came to be dubbed gedongan, from the Indonesian word for 'building', gedong. It marked the music as modern and progressive, as many traditional performances took place under the sky. Pop Indonesia musicians frequently cooperated with the Suharto administration, if only to prevent themselves from being accused of being leftist, something that had happened to many an Indonesian artist since the coup and subsequent large-scale persecution of (assumed) communists in 1965 and 1966. So-called soldier stages are a good example of such co-optation. Artists helped to popularize the regime's message of development through their performances at mass gatherings organized by the reigning political party.

However, pop Indonesia's claim to hegemony was not unrivalled. During the late 1960s, and following a genealogy not too far removed from that of the gambus-inspired acts, hybridization of Anglo-American popular music and Melayu (Malay) music took place, resulting in pop Melayu: a genre that, from the mid1960s onwards, enjoyed popularity in Indonesia as well as Singapore and Malaysia. Pop Melayu, as performed by Mus Mulyadi, Titik Sandhora, Lilis Suryani, and the likes, has its origins in the so-called orkes Melayu, Malay-language orchestral songs set to an ensemble that mixed Western instruments such as percussion, 
guitar, piano, or violin with indigenous instruments such as double-headed drum (gendang) and the seruling flute.

The ongoing competition between pop Indonesia and pop Melayu was easily won by the former. Pop Indonesia controlled most of the mainstream media and a recording industry that was, by then, firmly settled in the nation's capital. Pop Melayu resurfaced from time to time and in changing guises, but was always deemed utterly 'unmodern' by mainstream press and critics. Pop Indonesia, firmly seated on its throne next to its Western rock and pop twins, became the dominant narrative by which the history of popular culture in Indonesia is still told today. A tale of modernity and technological progress, much shaped by nationalist interests that seems little challenged, or are there other stories to be told?

\section{Subversive sounds}

Emerging from the unstable infant stage, many of the postcolonial nation states of Southeast Asia were slowly getting a grip on things and ever more daringly expressed their ambitions to citizens and the outside world alike. This resulted in master plans for progress and development of the nation, such as Malaysia's aforementioned New Economic Policy and Suharto's development nationalism. Yet, there are always alternative voices that challenge dominant state ideologies. Dissatisfaction with the nation's policies and disillusionment, caused by the fact that the promised modernization did not fully materialize, prompted social critique. Where and when modernization was successful it often did exclude large segments of society, similarly shaping the formation of alternative views on the nation's course. Frequently, these 'subversive' ideas found expression in music, notably popular music. In Indonesia, four musical trends were born out of this process: a renewed appetite for Islamic music, the rise of the protest song that promoted the nationalism of the republic's earliest years, the birth of dangdut as a music for the 
common man, and a return to traditional music, religious and ethnic, for musical inspiration.

In the 1970s, a worldwide 'Islamic resurgence' took place. It resonated especially with the post-colonial nation states of Indonesia and Malaysia, where the authorities tried to find a 'middle way' between the Communist Bloc and the West. Islam in all its guises increasingly became a way to express a distinct Southeast Asian identity. These two decades formed the foundational years of an Islamist movement, in which Muslim activists gave their alternative views on the government's master plans, often in musical form. The movement enabled this newly emerging group of assertive Muslims to carve out an identity of their own by providing them with fashionable and modern lifestyles.

For many popular music makers, dissatisfaction with the nation state emerged with the loss of what anthropologist and political scientist Benedict Anderson has called the 'deep horizontal comradeship', which epitomized the early Southeast Asian nations. Authoritarian and often corrupt regimes now ran the country in the Philippines and Indonesia, whereas in Malaysia the National Coalition advocated an agenda of Malay supremacy, to the exclusion of at least one third of its non-Malay population. Popular music provided one of the few arenas to speak up. Freddie Aguilar, the Philippines' most reputed folkrock musician to date, is one of the better-known exponents of such protest singers, putting 'the folk' back into folk music. His song 'Anak' ('Child', 1979) - the best-selling Philippine music record of all times - gained him international fame. Folk singer Iwan Fals is, in many aspects, Aguilar's Indonesian counterpart. With like-minded artists such as Leo Kristi and Harry Roesli, Fals belonged to the New Order's staunchest critics. Aguilar's version of the old patriotic kundiman song 'Bayan Ko' ('My Dear Country', 1986) became one of the most popular anthems during the first People Power Revolution of the mid-1980s. But much of his other song repertory is also critical of the corrupt Marcos regime. Iwan Fals (together with guitarist Sawung Jabo and their band Swami) is best remembered for his 'Bento' (1989). Even now, 
in more democratic times, it is his most appreciated song. Both Iwan and Freddy seem to have inspired some sort of populist musical nationalism that left little room for ethnic sentiment, but favoured the early nationalist revolutionary mood of their nations instead. Aguilar is commonly seen as an important contributor to the Original Pilipino Music (OPM) movement that became popular throughout the 1970s. It promoted ballads, sung in the native Tagalog language, instead of in the until then dominant English language.

Iwan Fals' music and public persona, as popular music scholar Jeremy Wallach has keenly observed, provided his audience with a compelling example of modern Indonesian manhood that was rooted in Sukarnoist popular nationalism and utopian democratic ideals that are, in a sense, not very different from the patriotic ideals of American rock star Bruce Springsteen. Like Springsteen, Iwan Fals performs a self-deprecating yet heroic masculine identity that is intimately connected with a critical, populist nationalism. It is no wonder that a popular representation of Iwan Fals found on T-shirts, stickers, and posters in outdoor markets throughout the archipelago, was that of the singer dressed like Sukarno, Indonesia's first president.

The third alternative sound came from the proponents of the same pop Melayu music briefly referred to above. Orkes Melayu and its successors were seen as music for the 'ordinary people' or the 'masses'. Elite youths regarded its musicians and audiences as kampungan, rural or backwards, simply because they played 'an older kind of music'. Yet, in uncertain times, the trans-national Malay identity served as a safe haven to those same musicians and audiences. Indonesia, Singapore, and Malaysia were young nations on the brink of chaos at that time, and a widely-shared Malay identity offered an alternative rallying point to the respective nations.

While throughout the 1970s pop Melayu slowly gave way to its near contender pop Indonesia, it was soon invigorated by some of orkes Melayu's most distinctive and leading artists, among them A. Rafiq, Mansyur S., Elvy Sukaesih, and Rhoma Irama. 
Named dangdut, this new hybrid had various, distinct audiences, but was, above all, music that stood 'close to the people'. As live music, it was an outlet for young, male, lower-class audiences. Female dangdut aficionados, in contrast, mostly listened to cassettes in their homes, where they also watched dangdut-inspired TV shows with often sentimental content. In contrast to the political messages in Rhoma's songs, more recent dangdut acts, such as Inul, Trio Macan, or Dewi Persik, seem more geared to unleashing sexual energy, much to the discontent of the 'King of dangdut' himself.

Lastly, as the idea of the centralized state and, perhaps, modern life and everything that came with it, began to lose its lustre, people turned back to their regional, ethnic roots. Ethnic, 'traditional' sounds had long been ignored by both state and industry, as they were deemed incompatible with progress and a modern life. Musicians found inspiration in their own regional music and wedded its sounds with those of Western pop music. This new hybrid became immensely popular, and will be delved into deeper in the remainder of this chapter.

\section{Making noise in the big melting pot}

The late 1970s was a time of rapid urbanization. In an attempt to initiate to modernize society and the economy, Southeast Asian governments promoted industry and the urban sector over agriculture and the city over its rural hinterlands. The result was an annual average increase of the urban population by almost five per cent, with metropolitan areas growing four to five times faster than the whole of the country itself. This was combined with a mind-blowing steady annual growth rate of GDP per capita of more than eight per cent in most of the Southeast Asian countries. Southeast Asian megacities like Greater Jakarta, the Kuala Lumpur Klang Valley conglomeration, and Metro Manila attracted people of different ethnic origins and became true melting pots. National and ethnic cultures mixed with each 
other and with global lifestyles. While such cities were meant to push Southeast Asia as rapidly as possible into the world economy, many of its inhabitants were still making a meagre living in the informal sector.

In these large cities, the emerging middle class struggled with its identity. Its members had left their hometown villages, but were not yet global citizens, at least not culturally. Living in proximity to so many different ethnic groups, the newcomers felt the need to mark their ethnic identity. This tendency made national policymakers fear political and social unrest and, in an attempt to quell ethnic sentiment, they resorted to various nationalist tactics, such as the folklorization of the regional arts in Indonesia. Those less content with such state policies increasingly felt the need to express an 'ethnic modern' sentiment. They achieved this by connecting familiar local traditions with foreign ideas and, especially, technologies. A recurring theme in this era is the idealization of village life, as opposed to life in the modern metropolis.

Musically, the ethnic modern project came about by connecting regional musical traditions, often rural in character, to the latest urban trends and newly imported Western instruments. Especially the introduction of the sampler during the 1980s is worth mentioning here, as it enabled musicians to record and perform without having to rely on a full orchestra. This device made musical practice a more affordable and better controllable business that could be done almost single-handedly from home. But as the sampler could not always emulate traditional tunings and instruments, these sounds were lost in the new musical mix.

The technology with probably the most enduring impact on the production and consumption of music in Southeast Asia is the audiocassette. The advent of cassette technology in the 1970s resulted in a decentralization and fragmentation of decadeslong state and multinational monopolies. Compared to old and relatively costly media like radio, cinema, and gramophone, the cheap cassette technology and the sampler facilitated grassroots musical initiatives, aimed at niche markets for genres hitherto 
overlooked and omitted by the industry. A direct consequence of the introduction of such technologies was that, in much of Southeast Asia, especially Indonesia, the 1970s and 1980s ushered in a golden age for regional pop music. Various regional genres like pop Minang or pop Sunda became so popular that, for years to come, regional stars would outstrip national ones in popularity. Most regional pop was produced far from the region that inspired it, i.e. in the nation's capital Jakarta. There, in the melting pot, migrants felt the need to articulate their ethnic identity. Only at a later stage did recording companies blossom in provincial towns like Medan, Padang, Bandung, or Makassar.

\section{What is so modern about the ethnic?}

Two observations about ethnic modern music or regional pop need to be made here. The first is that modern ethnic music is not as novel as it might seem. And second, modern ethnic music can take on different guises from one place to another, depending on its social context. One should always keep in mind when talking about this kind of music that 'ethnicity' and 'modern' are social constructs, and that their interpretations may vary over time and space.

Recording ethnic music is as old as the music industry in Southeast Asia itself, as has been outlined in Chapter 1. At the beginning of the twentieth century, foreign record companies targeted the local markets in Southeast Asia with recordings of local, 'ethnic' music. When, in the 1930s, first gramophone and then radio were introduced in the Netherlands East Indies, it was difficult to find a common denominator that would help shape a single market. Instead, ethnic genres such as Javanese macapat, Sundanese and Sumatran music were sold on record and aired on the radio. At the same time, modern technologies and mass media shaped and united new audiences and helped to create some of the most vivid national genres in the Southeast Asian region, such as kroncong and Hawaiian. The 
popularity of these overarching, urban musical genres can be explained, according to musicologist Philip Yampolsky, by the strong impulse of mass media to maximize the audience and to market to the masses.

These same fragmenting and homogenizing forces of new mass media were active in the 1970 s and 80 s. The cassette recorder, for instance, helped to disseminate Western pop throughout Southeast Asia. This urban type of music could simply be rerecorded with the help of a dual cassette recorder. Cassette tapes were affordable and the music and the lifestyle that they came to represent offered the masses new ways of identification and self-expression. New, trans-regional and, in some cases, transnational audiences were born.

For a considerable time, this low-cost enterprise put locally produced music out of the market as it involved much higher production costs (musicians, recording, and post-production editing). However, within a few years, most recording labels that had hitherto devoted their attention to re-recording Western pop recordings began targeting other markets, including pop Indonesia, but especially previously ignored small niche markets. In Indonesia, but also in other parts of Southeast Asia, this new recording technology was instrumental in forging other forms of belonging that were often diametrically opposed to nationalist sentiment. Regional or ethnic pop music turned out to be highly successful and not only in generating new bonds among migrants of particular regions now living in the larger Southeast Asian megacities. The creation of an often overarching regional style of music, the emblematic use of ethnic or regional traditions, and regional language standardization also led both migrants in the cities and the inhabitants of their home region to identify with a larger, 'traditional' community that undercut national loyalties. Being 'modern' no longer automatically meant giving up one's ethnic or regional culture in favour of a national one. The interpretation of what was 'modern' moved away from the nationalist discourse, as certain groups within the Indonesian society no longer believed in the direction the nation was heading. 
An ethnic song can be strategically articulated as modern in quite different ways, and what counts as ethnic music, even within a restricted timeframe of a mere two decades (1970s-199os) may be considerably manipulated. The case of the Indonesian song 'Rasa Sayange' is a telling illustration of this. 'Rasa Sayange' is an ethnic song that has been claimed by both Moluccans and Malays as part of their cultural heritage. While Indonesia can probably boast the first gramophone record to feature the song, recordings of the melody used as film music go back at least to the 1930s. Parts of the melody played on angklung (tuned bamboo shakers mostly used in Sundanese (!) music) can be found in the Dutch colonial documentary Insulinde Zooals het Leeft en Werkt ('Daily Life and Work in Indonesia', c. 1940), and the same melody underscores the Japanese anti-Dutch propaganda movie Marai No Tora ('The Tiger of Malaya', 1943). Another recording appears in the Indian movie Singapore (1960) and is sung in Hindi by two famous Indian playback singers, Lata Mangeshkar and Mohammad Rafi.

The different contexts in which the song has been used attests to its trans-national appeal, as well as to the flexibility of the label 'ethnic' in the context of modern music. In Malaysia, for example, the search for a modern, yet ethnically distinctive, music yielded nasyid as a recording genre. But as a religiously distinctive musical genre, it excludes other ethnicities present in Malaysia, such as the Chinese and Indian, regardless of their faith. In Indonesia, ethnic modern music has been produced in an even more complicated environment where ethnic and regional identities seem to have blurred in often confusing ways.

Indonesian pop or lagu daerah ('regional song') is targeted at the residents of a specific region, mostly, but not necessarily, members of specific ethnic groups. The better-known variants of such regional pop genres include pop Jawa, pop Sunda, pop Minang, pop Batak, and pop Ambon. Pop Sumsel, from South Sumatra's city of Palembang, is a far more arbitrary construct. It is a hotchpotch of several traditional genres sung in local ethnic dialects, including Komering, Ogan, Semendo, and Enim. 
Again, like ethnicity, daerah or 'region' happens to be a construct with a particular history and serving modern-day needs, such as political or commercial interests. To explain the popularity and success of some and the failure of other pop daerah genres, one has to look at the degree to which the genre succeeded in articulating a sense of 'authenticity'. Many regional genres were inspired by local classical genres. Some of the new local music styles, such as the West Javanese pop Sunda, were considered more authentic by performers and audiences than other regional pop genres. These pop daerah were the most successful. The performers of pop Sunda achieved this by using traditional instruments and retaining the Sundanese tone systems pélog and sorog. Pop Minang, from West Sumatra, is another example of a popular pop daerah that is surrounded by an aura of authenticity.

\section{The sound of longing for home: pop Minang}

Pop Minang is a cover term for a range of popular music genres from the West Sumatran region, where the Minangkabau population traditionally resides. Yet, the pop Minang industry initially started in the Indonesian capital Jakarta. Since olden times, Minangkabau migrants gathered and met through cultural associations. Minang-flavoured ethnic music recorded and produced in Batavian studios had been on the radio since at least the late 1930s. It was also in Jakarta that the legendary group Orkes Gumarang was formed by a group of Minangkabau musicians in 1953, shortly after president's Sukarno's call for a more indigenized entertainment industry. Orkes Gumarang played Minangkabau songs arranged and performed with Latin American rhythms, such as mambo, cha-cha, and rumba, in a style similar to artists like Xavier Cugat. 'Ayam Den Lapeh' (1952, 'My Chicken Ran Off'), an allegorical song about elusive love and composed by Abdul Hamid with lead vocals by the singer Nurseha, is still a pop Minang classic. 
Pop Minang placed a strong emphasis on lyrics and recurrently used metaphors like merantau ('to go abroad', see also box on 'going abroad'), and longing for one's 'native hamlet' or home. From its inception in the late 1950s, pop Minang was made to 'sound Minang' by citing and appropriating certain Minang songs, melodies, and tunings from a huge reservoir of traditional genres. Musically, pop Minang is recognizable by the use of Minangkabau instruments that were the typical carriers of the older genres, including the one-stringed viola ( $r a b a b)$, the long bamboo flute known as saluang, and the talempong (gong chime) orchestra. In the 1980 s, those traditional sounds were often emulated by resorting to samplers and mixed with disco and dangdut.

A key concept in Minangkabau culture that is widely celebrated in Minang performing arts and pop music is the so-called alam Minang. It denotes a West Sumatran cultural heartland, affectionately known as the 'motherland' or ranah bundo. Rather than an exclusively spatially defined geographical area, the motherland represents an emotional attachment to a recognizable landscape and especially community (urang awak or 'our people') that shares the same moral values. However, over time, the notion of both motherland and community have considerably widened. Minangkabau custom expects young Minangkabau men to seek fortune abroad and this is how the motherland came to span the whole world.

Unlike more traditional and localized West Sumatran music genres, such as rabab Pasisir or dendang Pauah, it was this genre of pop Minang that eventually appealed to the Minang community as a whole. No longer confined to a particular village of origin, pop Minang increasingly addressed an overall regional or ethnic group, including those Minang in the homeland and in rantau. To Minangkabau migrants in Southeast Asian metropoles such as Jakarta or Kuala Lumpur, the nostalgic sentiment of longing for home expressed in these songs is all too familiar.

Today, pop Minang is an established genre. The songs are not only performed by well-known Minangkabau artists, but also by nationally renowned non-Minang performers. Apart from 
prominent artists like Zaenal Arifin, Tiar Ramon, and Yan Bastian, Minang popular music throughout the 1970 s and 1980 s has been primarily associated with the female vocalist Elly Kasim.

\section{Village girl and big city pop diva: The story of Elly Kasim}

Elly Kasim was born in 1944 in Tiku Agam, deep in the heart of the Minangkabau motherland. At a young age, she moved first to Jakarta, then back to West Sumatra, and later to East Sumatra, before she finally settled in Jakarta in 1961. Already at this young age, Elly knew what it felt like to be a migrant and to long for loved ones far away. It was in the big city of Jakarta that Elly started her career as a singer. It was the heyday of Orkes Gumarang, and its song 'Ayam Den Lapeh' was widely aired throughout the country and enjoyed by all Indonesians, regardless of their ethnic background. It was this song that inspired young Elly to participate in a talent show organized by Radio Republik Indonesia (RRI) in Jakarta. Following her successful performance, she started performing with her uncle's band. Her fame spread and, before long, she was recruited by one of Gumarang's former members, the illustrious Minang composer Nuskan Syarif, who asked her to become the lead singer of his new ensemble Kumbang Tjari (1961-1963).

Together with Elly Kasim, Kumbang Tjari was the first to perform at the Indonesian national television studio (TVRI) in 1962. This studio was set up in anticipation of the Asian Games that were coming to Jakarta that year. With this group's exposure through national television, Minang music became part of the world of national entertainment. Recording with bands such as Kumbang Tjari, Zaenal Combo, and The Steps (the latter of disco fame, see the box on 'disco'), Elly rose to Southeast Asian fame and, with her as one of its most prominent voices, Minangkabau music was taken up by the blossoming Southeast Asian music industry, which was still dominated by foreign companies. Elly 
Kasim was the first Indonesian singer to be contracted by the Philips record company to make recordings abroad. She recorded in Singapore and Hong Kong, where she and The Steps were regularly on tour in the period 1969-1979. Many of these recordings were also released by local labels, such as Remaco, a tendency that was boosted by the shift to cassette tape releases in the late 1970 and early 1980s. Together with the cassette releases, Elly Kasim has over a hundred albums to her name, predominantly regional pop.

Gumarang's 'Ayam Den Lapeh' not only triggered other Minangkabau to perform modern-day interpretations of wellknown Minang classics, but also did much to raise similar sentiments among other ethnic communities in the capital. Although Elly and her fellow Minangkabau artists profited the most from the new musical developments sparked by Gumarang's mamboand rumba-flavoured Minangkabau hit songs, the former group chose to present traditional Minang songs in the style of Western rock and pop, which had become popular again in the early days of the New Order.

In the late 1970s, Elly Kasim married Nazif Basir, a journalist, theatre producer, and editor of various Minangkabau cultural periodicals. After her initial days of ethnic rock and the, at times, funky accompaniment of The Steps, Elly's approach to Minangkabau music in her performances became more traditional. She began to articulate Minangkabau culture and songs without necessarily combining them with foreign or hip elements and sounds. Minang culture was now no longer regarded as an obstacle, but as an asset for modern Minang migrants living in Indonesia's cities. From the late 1970s onwards, Elly and her husband led Sanggar Sangrina Bundo, a Minang dance and performing arts troupe that was regularly invited to the presidential palace to perform for foreign guests. The group was also sent abroad by the Ministry of Tourism to perform Indonesian and Minang culture abroad in countries such as neighbouring Singapore and Malaysia - where a large Minang community resides in Negri Sembilan, Thailand, the Middle East, and Europe. The participation of Elly's Sanggar 
Sangrina Bundo in these New Order government-initiated tours proved that Minang regional pop, initially a marginal music genre, had become fully incorporated into the national culture.

Both in her songs and visual presentation, Elly Kasim alternated between her Minangkabau roots and the image of the modern city girl. The audience saw her don folkloristic Minang outfits, seated on an old-style water buffalo cart, but also dress in the latest urban fashion complete with sexy sunglasses and seated on the back of a motorbike in Hong Kong. Elly and her repertoire epitomize a generation of migrant city dwellers stuck between two worlds: their home village and the big city. Pop Minang formed, and still forms, the soundtrack of their lives.

\section{Box 3.1 Disco}

In the 1960 and 70 , professional backing groups often accompanied Indonesian singers on their records. The Steps, led by drummer Ismet Januar, was one of the established groups. They accompanied many singers, including Diah Iskandar, Elly Kasim, and singer-actress Marini, as well as their own band members Paul Irama and May Sumarna. They were versatile and played whatever style was in vogue at the time, from rock and roll and pop kroncong to soul and especially disco. Throughout the 1970s, The Steps recorded several disco albums including Non-stop Soul (recorded in Hong Kong) and Peep-Peeh-Yeah. Most of these albums contained Indonesianlanguage versions of hits by international artists such as KC \& The Sunshine Band, ABBA, the Bee Gees, or Wild Cherry (notably, the latter's 'Play That Funky Music'). The song 'Mari Ke Disco' ('Let's go to the discotheque') by The Steps has all the characteristics of the disco sound, but also contains elements of earlier soul and funk styles. Such renderings of international disco songs in local languages persisted well into the early 1980 s. They were found on cassette tapes, as part of 'disco medleys'.

Not everyone was a fan of this foreign disco music and its novel youth culture. Released in 1979, at the height of the disco craze, the song 'Mat Disko' by Malaysia's star entertainer Sudirman Arshad (1954-1992) 
presents a satirical take on some of the sillier aspects of contemporary popular youth culture. Musically, the melody and song structure owe more to quasi-ethnic pop Melayu than to actual disco songs of the era. The arrangement, however, contains all the markers of a 1970 disco song, including the then-popular'syn-drum' fills and rhythm guitar playing in high octaves. 'Mat Disko' is clearly influenced by the sound that was popularized by artists like the Bee Gees in the movie Saturday Night Fever, as well as by 'blaxploitation' themes like Isaac Hayes'Shaft. The lyrics form a humorous commentary on the behaviour of people who are desperate to be considered young, modern, and 'cool', but who only succeed in making a fool of themselves.

\section{Box 3.2 Dangdut}

Dangdut is a genre of Indonesian popular music that coalesced in the capital of Jakarta during the early 1970s. Dangdut has its roots in orkes Melayu, 'Malay band music', which itself was heavily influenced by Indian film music and Middle Eastern popular music of the 1950 s and 1960 s. Today, its broad appeal and wide circulation via electronic media (radio, audio, and video recordings, television, the internet, and cellular/ring back tones), and the fact that its audience comprises the majority of Indonesia's population, have earned it the moniker 'Indonesia's most popular music'. The music accompanies dance at all kinds of events, such as family celebrations (primarily weddings and circumcisions), product launches, and concerts. Dangdut bands provide entertainment at nightclubs, karaoke bars, and massage parlours, where large quantities of alcohol and cigarettes are consumed. But throughout the 1980 s and early 1990s, dangdut was also performed frequently at political campaign rallies and to entertain police and military personnel.

Dangdut was originally associated with Melayu and Indian film music. In the early 1970s, Rhoma Irama, known as the 'King of dangdut', brought the sound and performance style of American and British rock music into dangdut. Later, the genre was re-signified as national in the 1980s and 1990s, and evolved into a kind of 'ethnic' and 'regional' music in the 2000s. Regional or ethnic forms of dangdut 
incorporate regional languages, traditional musical elements, and performance practices. They are marketed to specific ethnic communities in Indonesia. Many regional forms of dangdut crystallized in the mid-1990s in conjunction with the changing landscape of politics and economics, greater access to technology, lack of enforcement on locally produced recordings, and the decentralization of the music industry.

Dangdut is primarily vocal music sung by both male and female artists, accompanied by a band of male musicians. The standard set of instruments consists of two electric guitars (rhythm and lead), electric bass, a small two-headed drum (gendang), a side-blown bamboo flute (suling), and an electronic keyboard. Dangdut lyrics are generally set in the Indonesian language, addressing themes of love and male-female relationships, everyday life, and social and political issues that affect ordinary Indonesian citizens primarily belonging to 'the middle classes on down' (kelas menengah ke bawah).

\section{Box 3.3 Going abroad (in two songs)}

Labour migration ('merantau' in Indonesian) is an important aspect of life for large numbers of Southeast Asians. It is therefore not surprising that there are many songs dealing with this theme. The renowned song 'Merantau' is sung in Indonesian and does not mention any specific locality or region, but, instead, treats the theme of migration in general terms, focusing on the feelings of loneliness and longing for family and the home village. The song's original performer, Titiek Sandhora, from Brebes in Central Java, was a household name in the late 1960s, when her songs could be heard almost daily on a rapidly increasing number of private radio stations. 'Merantau' is a guitar-based ballad of a type that was popular throughout the 1960 s and early 1970s. Composed by Jasir Sjam, who also supplied song material for many other singers who were popular at the time, including Anna Mathovani, Bob Tutupoly, Tety Kadi, Ernie Djohan, and Ida Royani, it received recognition as the most popular song among Indonesian military personnel in 1972. 
Illustration 11 Radio Prambors was launched in 1971 in Jakarta. Airing pop music, Prambors was a teen icon in the 1970s-1990s period. Nowadays, Prambors FM is Indonesia's ‘No. 1 Hit Music Station’.

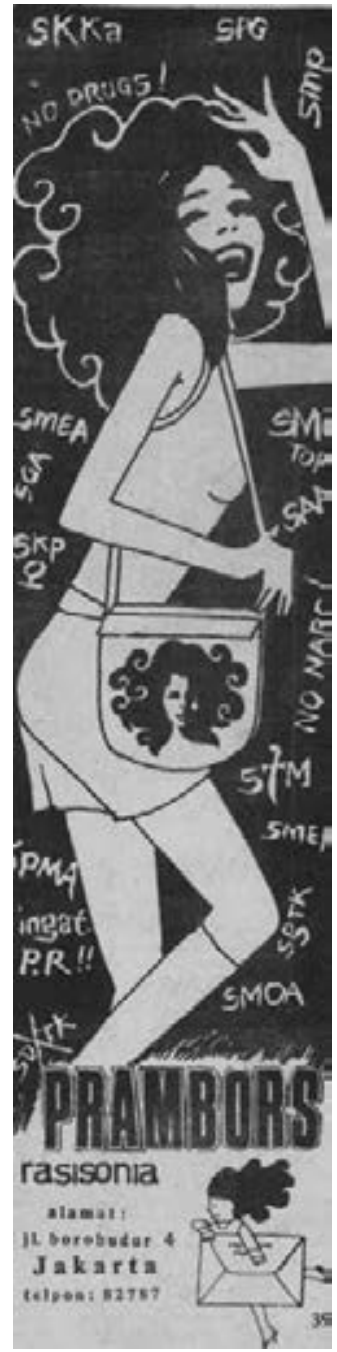

Indonesian youth magazine Aktuil, 1974 KITLV collection 
However, there is probably no song that captures the emotion of melancholic longing for one's homeland better than Ernie Djohan's 'Telok Bayur'. The song, composed by Zaenal Arifin and accompanied by his Zaenal Combo, was written in the mid-1960s, but as an album (Telok Bayur) was only released in 1973, which says something about the longevity of the song's popularity. Musically, it falls within the mainstream of the guitar-based beat/rock and roll styles of that era. Ernie Djohan (1951), herself much of a migrant, was born into a diplomat's family and has been accustomed to having to move to new and unfamiliar surroundings. She lived in the Netherlands and in Singapore, where she won several talent awards while still in high school. Ernie Djohan is of West Sumatran (Minangkabau) descent, and it may not be coincidental that 'Telok Bayur' (referring to a harbour in the Padang region, from which many migrants left) is a song of yearning for the homeland and loved ones. Minangkabau custom requires young Minang men to gain experience and accumulate wealth outside West Sumatra before returning home to start a family. 



\section{Doing it Digital, 1990s-20oos}

Relatively affordable means for producing and distributing music have, over the last two decades, facilitated the spread of novel popular musical genres in Southeast Asia. But at their foundation lay reactive sentiments prompted by contemporary political and social issues. Experiments with ethnic pop, fusion, and world music remained popular in Southeast Asia in most of the 1990s, albeit in diverse guises. In Malaysia, ethnic music, often in tandem with nationalist policies, mostly came to stand for a revival of 'indigenous' (read 'Malay') genres such as dondang sayang, zapin, and joget. Its most popular advocates were Malaysian pop singers Noraniza Idris and Siti Nurhaliza. Both singers are reputed performers of irama Malaysia, a fusion between the more traditional styles just mentioned and an Anglo-American pop idiom. In Indonesia, regional pop songs have, similarly, remained a popular format to express ethnic sentiment, with, in particular, pop Jawa and pop Minang doing reasonably well in terms of commercial success. Online radio explains why such music genres are now also popularly consumed by Javanese or Minangkabau migrant communities abroad, in Europe, the United States and as far as Latin America. In line with postmodern preferences for mash-up, collage, and the local appropriation of globally circulating trends, fusion and especially world music have also gained some currency in the Southeast Asian pop industries. A good example of the latter is the 1993 song 'Denpasar Moon', which achieved great commercial success in Indonesia and across most of Southeast Asia. Based on a generic Western pop style with a prominent back beat and largely played on electronic instruments, the song incorporates sounds and musical patterns derived from various Indonesian/ Asian genres, including dangdut percussion, gamelan gongchime sounds, and melodic scales that evoke associations with Sundanese musical instruments, such as the degung or kacapi suling. The fact that the song was created by an Englishman 
and interpreted by a Filipina living in Indonesia underlines the trans-national origins and appeal of the song.

\section{Musical revolutions: Finally indie-pendent?}

At the turn of the twenty-first century, there are more postnationalist musical histories to be told. By far the biggest challenge to the musical status quo - read: an industry that either prefers global pop genres or national renderings such as pop Indonesia, rock and, increasingly again, jazz - has been a thriving trans-national youth and counterculture. Especially in Indonesia, where technological innovations of the late 1980s, together with the changing political climate since the late 199os, resulted in a music scene its practitioners commonly refer to as the 'alternative' or 'independent' music movement, popularly nicknamed 'indie'. Indie is a collective designation for various groups, genres, and scenes that prioritize a do-it-yourself (DIY) attitude and therefore prefer small independent or even internet-only labels ('netlabels'). They occasionally promote a rebellious image, but not necessarily so. Although some of the bands, genres, and labels involved in the indie scene clearly predate the political changes that followed in the wake of Suharto's fall in 1998, most of these alternative voices have only become public with the loosening of restrictions on media and public life in general after this date. Particularly local and campus radio have been instrumental in highlighting underground bands by playing demo tapes and organizing events. The popularity of online streaming radio in the early $2000 \mathrm{~s}$ resulted in yet wider audiences. Better-known radio stations like Jakarta-based Radio Prambors, stations that habitually ran their own indie charts, picked up indie acts. With local indie musicians going digital, they soon went international. Streaming radio and social media disseminated music that no company dared to release, now with an audience that potentially reached beyond national borders. 
Rather than just a musical genre, indie reflects the approach of some Western pop traditions that articulate a DIY ethos combined with the cultivation of a rebellious image. As a consequence, indie music so far has comprised a wide range of styles and genres, oscillating between ska, techno, ethnic (for example, the Palembang-based modern folk group Semakbelukar), experimental, and metal music. Southeast Asian youth have typically indigenized much of these musical cultures and provided them with new meanings and new audiences. The hardcore metal band Puppen was one of the early pioneers of Indonesia's independent music scene for the ten years following its formation in Bandung in 1992. Puppen initially built a following with live performances at schools, universities, and at a venue located at the Saparua Street, a hot spot of the 1990s Bandung indie scene. Today, Bandung and Jakarta are still reputed as the home of a large number of punk bands. Some of these groups and associated movements are anti-capitalist oriented (for example, the Riotic Collective and, more recently, Balai Kota DIY Collective, both from Bandung). In Kuala Lumpur, the Ricecooker Shop specializes in metal and punk music. Self-produced Malaysian fanzines, such as the Aedes magazine, similarly pioneered a punk spirit from the early 1990s onwards, although the scene never became as big as in neighbouring Indonesia. Yet, it is not punk or metal, but the sound of independent Brit Pop that became dominant, with bands such as Indonesian Sheila on 7 and Cokelat among its early 2000 s epigones (see box 'Two Indonesian indie songs'). These bands found inspiration in particular in Brit Pop from the 1990s, which became widely available to Southeast Asian musicians and music lovers around that time thanks to pirated $\mathrm{MP}_{3} \mathrm{CDs}$ and file sharing sites.

But even indie, with its promise of the 'alternative', holds contradictions, as some examples of Indonesian indie acts prove. Bandung rock band Cokelat, widely seen as pioneering the indie sound during Indonesia's political reforms of the late 1990s, surprised both fans and the larger audience in 2006 by recording an album of nationalist evergreens, including their own hit single 


\section{Illustration 12 Sumatran punk youth, 2008}

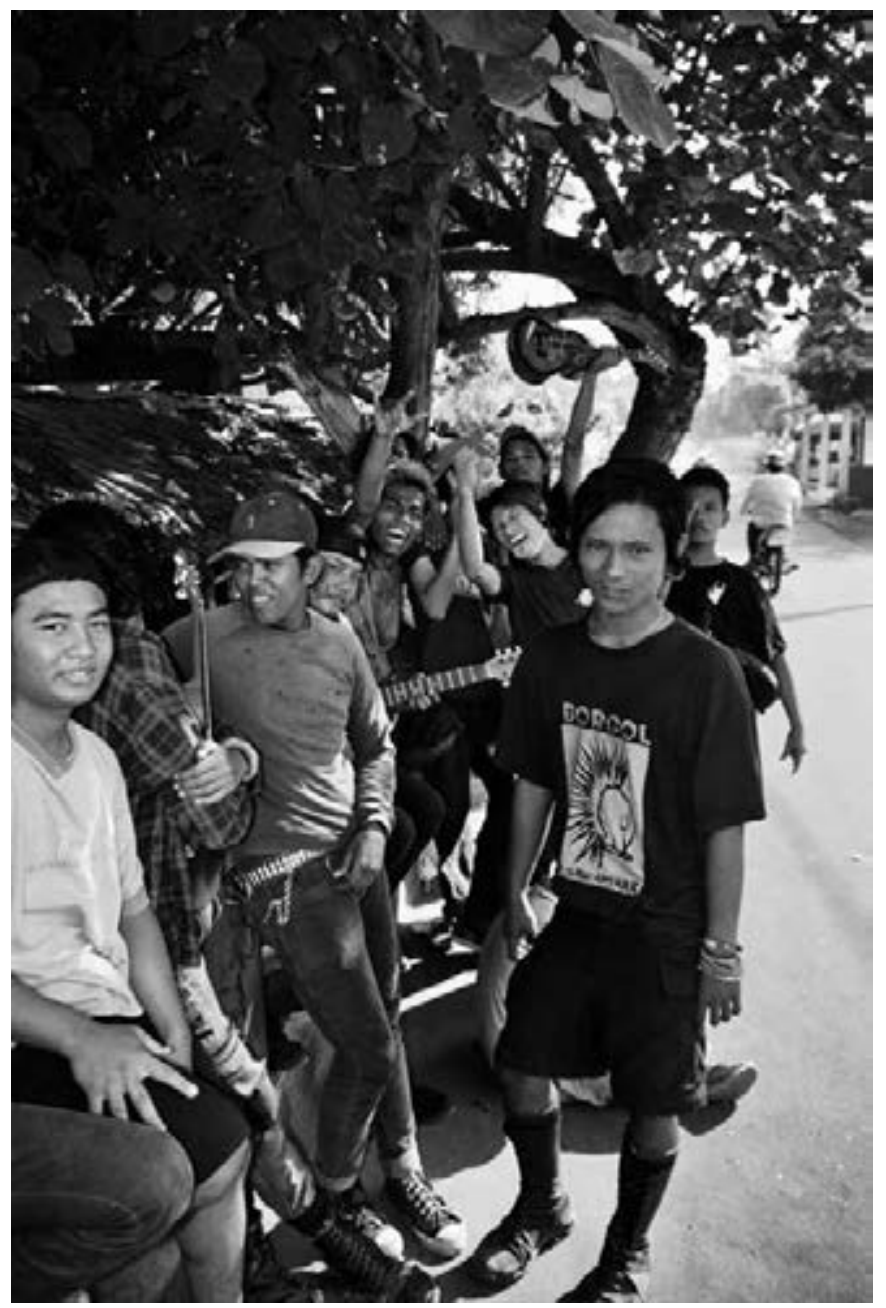

Photo by Marc Veraart, Creative Commons

'Bendera' ('Flag'). The song would later become an unofficial anthem for the Indonesian UNIFIL Peace Corps in Lebanon. This case shows that an alternative culture may question the state, but seldom the nation. And while happily promoting the idea of 
being alternative, indie music, as all other music genres, comes with questions of good versus bad taste and its own innate class contradictions. The Kangen Band from Lampung in South Sumatra surprised many observers with the nationwide success of their 2007 debut single 'Tentang Aku, Kau Dan Dia' ('About Me, You, and the Other'). Several musicians on the national music scene, who (with the exception of dangdut performers) cultivate an urban and middle-class lifestyle, voiced harsh criticism of the band's limited musical skills and, especially, its low-brow audience.

While, in past decades, Indonesia has seen a revival of regional cultures, the appeal of music from what is seen as 'peripheral areas' has generally been limited to local audiences, and mostly to the lower socio-economic classes. For a group like the Kangen Band, whose members openly acknowledge and embrace their provincial image, to enjoy nationwide commercial success as well as a certain degree of mainstream recognition had previously been unheard of. Some voices in the press have framed the story of the Kangen Band in terms of the growing assertiveness of the lower social classes claiming their place in the national public space.

However, having started as an alternative movement to counter the hegemony of big labels and big capital, many of the indie bands of the first hour have now made it big themselves. Indonesian band Effek Rumah Kaca being a case in point, but also successful Malaysian acts such as Hujan and Bunkface have recently earned mainstream recognition. This leads some, including anthropologist Brent Luvaas, to argue that Indonesia's indie scene, emerging at a moment of massive market reform, 'has always been as much a mode of entrepreneurship as a bastion of free expression'. Central to his argument is the distro, referring to the global punk phenomenon of small, autonomous retail spaces that sell locally produced music and clothing. Some of them even offer their own record and fashion label. Distro cater to a young, urban, and aspiring middle class that wishes to combine a rebellious image with affordable good looks. The efforts of the members of the indie movement in Indonesia to redefine themselves through music and fashion are inseparable from the efforts of the island nation to re-brand itself 
as a creative economy, Luvaas argues. Similar things can be said of neighbouring Malaysia and Singapore, although in absence of a true political reform, the indie movement has never really gained political momentum as it did in Indonesia.

Today, indie music comes with its own (online) magazines, charts, and awards. The Indonesian ICEMA awards, for instance, 'celebrate twenty years of independent music movement'. Digitally enabled platforms, such as social network sites (MySpace was initially big in most of Southeast Asia), blogs specializing in music, and especially file sharing sites such as SoundCloud (see box on 'SoundCloud communities') have yielded a youth culture that is at once very local and truly trans-national. Musical acts from various Southeast Asian nations appear on par in online magazines such as indieJakarta.com and the Malaysian the WKND blog, and at regional outdoor festivals such as Good Vibes (Malaysia, since 2013). Digital communication and affordable intra-Asian air traffic have turned the region into a new and promising playground for Southeast Asian musicians and their audiences. Festivals have been increasingly profiting from these developments.

\section{Pop, politics, and piety}

But indie should not be seen as the sole revolution in recording industries. Cheap grassroots technology offered new affordances to hitherto neglected genres and communities in the 1970s and 1980s, and now digital technologies only amplified these successes. Existing popular music genres developed further and saw their audiences grow even bigger. The spectacular story of contemporary nasyid forms an illustrative example of this.

Nasyid is the generic label for all songs with Islamic content and the implicit aim to convey a moral message and spiritual advice. This religious musical style was especially popular in the period 1995-2005, when it took Muslim audiences throughout Southeast Asia. Today, nasyid continues to be produced and consumed in cities and towns with a large student population and strong Muslim 
activist tradition. The genre attracted a mass audience because its songs addressed questions on how to be a modern Muslim youth in Southeast Asia, reconciling piety with a consumerist lifestyle ranging from Muslimah day spas, Islamic lifestyle glossies and teen lit, halal food processing, but also modern Muslim entertainment such as Malaysia's Imam Muda ('The Young Imam') reality soap. Also, nasyid expressed political aspirations of Islamist movements in both Indonesia and Malaysia.

In the late 1970s, inspired by the success of El-Suraya from Medan, all-female ensembles such as Singapore-based Al-Mizan and Hidayah had brought nasyid within reach of the recording industry. Most of today's better-known nasyid ensembles trace their origins to the Malaysian missionary movement Al-Arqam. In the mid-1980s, Arqam organized cultural happenings, poetry recitals, and concerts with Islamic music in hotels and other public places in an attempt to posit an alternative to Western popular culture. Southeast Asian nasyid started out as mostly unison singing by choirs of young men, of lyrics set in the Malay language. The songs were rich in Arab-like vocal ornamentations. Arqam groups such as Nadamurni (1988-1994) and the Zikr (1992-1995), soon started experimenting with harmonized vocals and the addition of percussion and a modern Western drum kit, but all of their music was still acoustic. It was the intensity of vocals and, in particular, the directness of the lyrics that apparently struck a chord with listeners. Two main themes can be discerned in the lyrics. The first one is nostalgia: references to childhood experience, parental love, village harmony, and life in the countryside. The second theme pertains to the need to defend one's integrity and religious values towards the outside world.

With an official state-imposed ban on all of Al-Arqam's activities in Malaysia in 1994 and the movement being disbanded, former Arqam members started new nasyid acts such as Rabbani and Hijjaz. However, it was especially the group Raihan that turned nasyid music into a modern and fashionable genre that was taken up by the entertainment industry. Its 1996 album Puji-Pujian ('Verses of Praise') is still the best-selling Malaysian 
pop album of all times. Groups such as Raihan were ambassadors of Malay and Muslim culture both in their own country and abroad. They introduced new elements into nasyid, such as Latin and African percussion and even gospel-like choirs. Sometimes, such musical experiments stirred controversies both within and outside orthodox Muslim circles. To some, this was too much pop added to what they considered as an ancient spiritual genre; others feared a religious invasion of an otherwise secular music industry. Remarkably, nasyid singers do not consider nasyid to be just a musical genre, but primarily a spiritual practice: practise what you preach or sing. Without clear musical definition, the genre thus easily continues to renew itself; the latest generation is experimenting with crossovers into rhythm \& blues, hip-hop and even rock music.

Popular among Islamist activists at Indonesian and Malaysian campuses, nasyid gained momentum when the dictator Suharto stepped down and more room was created for Islamic expressions. Many Indonesian nasyid groups, like SNada and Izzatul Islam, have used their music to support the Justice Party (PKS, later 'Prosperous Justice Party'), a politically fundamentalist Islamic group popular among student activists. However, only from the late 1990s onwards, and fuelled by the successes of the Arqam groups, did student ensembles in both countries start recording their own nasyid songs. The ensembles were increasingly modelled on globally popular boy bands, such as the Backstreet Boys or Boyzone, while the lyrics explicitly addressed a teenage audience. The casual sound and look of Malaysian and Indonesian nasyid ensembles such as Inteam, Mestica, and again SNada, have been taken up elsewhere and have set a trend for global Muslim celebrities, such as Maheer Zain, Zain Bhikha, and Sami Yusuf, who today enjoy a large and dedicated following, especially in Southeast Asia.

Nasyid music is the most visible and popular musical expression of Islam to be taken up by the entertainment industry to date, but it is by no means the only one. A short-lived fad of pop religi ('Islamic Pop'), including groups such as Unggu and Wali, was 
similarly successful in addressing the aspirations of a young, urban Muslim middle class, particularly in Indonesia and Malaysia. Soundtracks to popular Islamic films such as the 'Verses of Love' (Ayat Ayat Cinta, 2008) or 'Women with a Turban' (Perempuan Berkalung Sorban, 2009), are yet another means for Islam to gain public visibility. With the pressure of globalization felt by many Southeast Asians and a nation state that does not always seem to have lived up to its early promise of (a convincing) modernity for all citizens, urban audiences region-wide increasingly tried to find other ways to anchor shifting identities. Today, the worldwide ummah, ironically very much a shifting entity itself, still seems to offer a safe haven away from global complexities and national turbulence. At the same time, the concept of a global Islamic community is successful as it stresses a cultural difference from what many see as global trends imposed by the West.

\section{Asia around the corner}

The influence of nearby East Asian popular culture has always been felt in Southeast Asia, not least because of the presence of considerably sized communities of overseas Chinese in the region. Whereas Chinese entrepreneurs, artists, and producers have stood at the base of the early recording industry in Southeast Asia, Chinese-language music has not always fared equally well in each of the Southeast Asian countries. For decades, Chineselanguage songs flooded a considerable part of the Malaysian and Singaporean market. Especially popular singers such as Yao Surong gained quite a following all over Southeast Asia. In light of Surong's trans-national popularity, it is interesting to note that in the early 1970s her songs were banned in her native Taiwan for being overly sentimental and spreading an 'unhealthy moral'. While her Mandopop (Mandarin-language songs, mostly produced in Taiwan, but consumed throughout the whole of Asia) was also readily available in Indonesia, Chinese-language songs were at least publicly absent for most of the later New Order era, except 
for some accidental Cantopop songs or 'nightclub songs'. The latter were sung in Cantonese and released on cassette with compilations of soundtracks to popular Hong Kong movies. Whereas more recently the tide seems to have changed and public expression of the Indonesian-Chinese minority is possible in present-day Indonesia, it has not, as yet, stirred a Chinese musical renaissance.

In contrast, Japanese - and later Korean - pop music fared much better in Southeast Asia. Its popularity started with the airing of Japanese TV dramas, the consumption of Japanese computer animation (anime) and comic books (manga) by a teen generation, and, to a lesser extent, in the early 1990s, the consumption of so-called J-Pop, a term referring to a wide range of modern Japanese popular music genres. In an era when Southeast Asian politicians tried to promote Asian values and Japan was economically thriving, especially the newly emerging and aspiring middle classes of Indonesia and Malaysia were impressed by what seemed to be an Asian version of all things modern. It was now 'cool to be Asian'. According to some, it was the cultural proximity to Japanese culture that facilitated the easy adaptation and local appropriation of the J-Pop aesthetics. But there were also fears that this Japan-mania would lead to cultural colonization.

The much-watched multilingual musical variety television show Asia Bagus ('Beautiful Asia'), produced in Singapore largely with Japanese money and featuring performers from all over Asia, was similarly linked to emerging notions of Asia as a cultural entity. It is an illustration of how flow of capital, performers, and media products cross-hatched East and Southeast Asia. The show, which was broadcast from 1992 until 2000, produced now-famous Southeast Asian singers such as Malaysia's Amy Mastura and Indonesian glamour lady Krisdayanti. MTV Asia, one of the first all-music channels that started in the early $2000 \mathrm{~s}$ and regularly played video clips from various Southeast Asian countries, including a weekly all-Indonesian chart (Ampuh List), was yet another effort to mark (Southeast) Asian music as one node in the global cultural market. 
Although Japanese drama is no longer regularly broadcast on Southeast Asian television, J-Pop still attracts a steady following. Among Indonesian youngsters it is still fashionable to don their hair in typical 'Japanese style' as advertised by saloons, and Japanese-flavoured events are still commonly found in some of the larger cities. Big festivals such as Jak-Japan Matsuri and Japan Pop Culture have been organized by the Japanese Embassy in Jakarta, in cooperation with Indonesia's Tourism and Creative Economy Ministry, and starred homegrown acts such as J-Rock and JKT48 (see box on 'JKT48').

More recent is the surge of Korean pop (K-Pop) culture, the tremendous popularity of which is partly explained by its initial association with the previous Japan Cool. In what is generally dubbed the second 'Korean wave' or Hallyu, it is no longer Korean television dramas such as the famed Winter Sonata (2002), Princess Hours (2003), and Full House (2004), but Korean boy and girl 'idol bands' that, since the early 2010s, have gathered a large following in countries such as Indonesia, Malaysia, the Philippines, and Thailand. K-Pop combines modern global genres such as electro-dance, urban, and hip-hop with slick and well-timed choreographies of groups consisting of six or more members. Target audiences are trend-conscious and fashionable teens all over Asia. Digital platforms such as YouTube and digitally distributed albums facilitate the creation of a global audience. But K-pop successes also inspire Southeast Asian artists to copy and adapt this musical style. So far, this has resulted in homegrown K-pop acts like Indonesian Cherrybelle, S.O.S., and the boy band $\mathrm{S}_{4}$. The latter two are products of Galaxy Superstar, an Indonesian televised talent show that trained the candidates in South Korea and offered the finalists a recording contract.

K-Pop and J-Pop primarily became a hype in the region because they offered a young generation, eager to carve out an identity of its own, Asian alternatives for a Western modern identity. However, it should be noted that most such popular cultural expressions were part of a well-orchestrated effort by both the state and the private sector to promote national creative 
and tourist industries abroad. This resulted in a tendency among Southeast Asian authorities to emulate these East Asian successes and use local pop expressions to promote what may be the next craze of Asian Cool, Indopop.

\section{Doing it Digital: Three apparent paradoxes}

Well into the twenty-first century, one can discern a number of paradoxical processes in the field of Southeast Asian music that make it difficult to predict how popular music will develop in the near future.

First, with the ongoing digitization, consuming music has gradually become an ephemeral practice. The sale of CDs has dropped to an all-time low as music lovers increasingly consume their music through YouTube. Music is owned and/or stored in increasingly smaller formats, on USB or $\mathrm{MP}_{3}$ devices, in mobiles phones, or on shared hard drives in internet cafes. That is, if users still bother to collect music at all, since the possibility of streaming and platforms such as Spotify provides listeners with an almost infinite choice of music to listen to at the time and place of their choosing. Internet radio or net labels add to this mix. There is more music available than ever before, but the sound quality is increasingly poor. And the more music we are able to listen to, the less it seems to stick.

One can speculate whether this new, fleeting nature of music in general is in some way linked to the fact that, since the 2000s, popular music has been commoditized in more ways than just the auditory. Merchandise and live gigs are as old as the industry itself, but nowadays artists cannot afford to do albums without also considering other, mostly visual, formats. Music TV is one of them, and the growing prestige of the annual contest for Indonesian popular music videos (Video Music Indonesia) from 1999 onwards is illustrative of this trend. Karaoke discs, video CDs with accompanying richly illustrated booklets, and YouTube channels are other examples. 
Second, the immateriality of today's musical practice seems to have prompted the urge to salvage what increasingly is no longer there, with the help of the digital techniques that are now at hand. This 'archive fever' has led some Southeast Asian music collectors to put online whole collections of digitized old vinyl records or $78 \mathrm{~s}$, complete with scanned sleeves and additional comments, among the latter (re)written biographies of their favourite stars. Such initiatives make rare music collections available for other likeminded music aficionados. A whole new generation of Southeast Asia pop music lovers is introduced to previous musics, be it punk, industrial music, or 1970s disco. Salient is their rekindled interest in what can be considered their own 'auditory heritage', the music their parents listened to thirty or forty years ago. The renewed interest in older musical genres has led many artists to appropriate and reinterpret these sounds of the past. Jakarta-based art collective White Shoes and the Couples Company is one of the groups that musically reference popular music from older times. This indie pop band, started by students at Jakarta's Institute for the Arts, released its self-titled debut album in 2005. Both their music and accompanying visuals blend contemporary indie aesthetics with retro influences, particularly 196os and 1970s film music and 1930s jazz and swing. In neighbouring Singapore, famed singer Dick Lee similarly reinterpreted his own sound heritage two decades earlier, proving the retro sentiment to be of all times. Yet, digital means just make musical inspirations more freely and easily accessible. With the rise of the collector and amateur discographer - copyright issues keep him from going professional - a novel sort of connoisseur and tastemaker has appeared.

But digital technologies have also facilitated wannabe singers and musicians with affordable means to produce and distribute their own music. A good example is the song 'Keong Racun' ('Poisonous Snail'), originally performed by an Indonesian dangdut singer named Lisa. But the song only got noticed by a larger audience when two teenage girls from Bandung, Sinta and Jojo, decided to do a coquettish and lip-synced version of the song and put it on YouTube. In no time, the clip went viral turning the girls, not Lisa, 
into instant celebrities. At the same time, the clip triggered a flood of user responses and other remixed versions of the song. Ironically, it was the vocalist of another renowned Bandung band, ST12, who later bought the rights to the song. He had the song re-recorded with vocals of another duo, but with Sinta and Jojo re-appearing in the video to lip-sync the song. This case shows that the music industry quickly responds to and incorporates such new grassroots initiatives, and that the much-hyped 'user-generated content' is typically something that may feed an increasingly neo-liberal industry, leaving much of the production work now to consumers.

In an era where the practice of not only user-generated content, but also 'prosumers' and 'selfies' travels extraordinary well, Southeast Asian pop industries also seem to have embraced the potential of what media scholar Chris Rojek calls 'celetoids': a shift of focus from elites to a celebration of the ordinary. Today, everyone wants to be a star, or, if not, at least to be among the stars, and modern-day idols are typically those easily within reach (see also box on 'JKT48'). The trend of retouching photographic materials that gained momentum with the availability of sophisticated yet affordable digital techniques now offers fans of JKT48 the chance to have their images inserted into pictures with their favourite members of the group. But also in other ways ordinary Southeast Asians are creating their own moments of celebrity. Young, mostly female fans, for instance, are depicting themselves having explicit relationships with their K-Pop or other idols in online fan fiction. Tribute bands and cover dance, in which young Thai, Filipino, or Indonesian fans mimic the dance choreographies of their idols, are ways of narrowing the gap between artist and fan.

The global format of televised talent shows is probably the best example of this 'celebration of the ordinary', one that actually has a surprisingly long tradition throughout Southeast Asia. For decades, talent shows have been a fruitful way of monitoring new trends, talent, and upcoming audiences. Singapore in the 1960s knew its Talentime contests and entertainers that were deemed to be the be-all and end-all of Singapore. There was, for instance, the island nation's own Cliff Richard, who rendered the artist's songs 
in Malay. Today's televised talent shows are different than those of the fifties and sixties, as they shift from celebrating celebrity to celebrating the ordinary. They come with the promise of no matter how fat, queer, ugly, young, or old, any ordinary person can, against all odds, become a celebrity in his or her own right. In the process, popular culture has, more than ever, become an arena in which to comment on and transgress societal values. As a consequence, Islamists, gays, ethnic minorities and whatever other 'likely unlikely' candidates have made it to the finals in idols shows such as Suara Indonesia or Malaysian Akademi Fantasia.

A third and final paradox is found in the fact that cheap digital means and a widespread DIY mentality have facilitated the emergence of local musical scenes and communities with an often very pronounced local taste. At the same time, this makes it possible for these local communities to become connected with yet larger communities beyond the nation or even the Southeast Asian region. Examples of such so-called glocal - a combination of global and local - contexts have been mentioned earlier in this chapter: pan-Asian entertainment or pop Islam. Yet another example is the almost global reach of Indonesian netlabels such as Yes No Wave Music, Ear Alert, or Stone Age Records. They not only promote local musics, but also other music that is shared between friends and family through SoundCloud and other social media related accounts (see box on 'SoundCloud').

\section{The Malay Muslim girl-next-door: A deeper conversation with Yuna}

If there is one particular artist whose career so far illustrates tendencies discussed above, it is the young Malaysian singersongwriter Yuna.

Yuna, born as Yunalis Mat Zara'ai, belongs to a new generation of artists who have succeeded in reaching a global audience by using the possibilities offered by inexpensive digital home recording and the internet, in particular social media such as 
MySpace. But her career is also to be understood against the background of the Klang Valley singer-songwriter scene in Malaysia, which gathered pace in the late 1990s and 2000s. This scene can be traced to an earlier cohort of performers including Dr. Wan Zawawi, Kit Lee, and Markizah (or the duo Passion), who all performed original material written in both English and Malay, and who mostly recorded and disseminated their music through self-funded limited releases. This singer-songwriter scene further matured during the late 1990s and 200os, with events like the Songwriter's Round, AcousticJam, and the Unclogged series, which took place at local bars, halls, and cafes in Kuala Lumpur. In 2005, the annual Malaysian singer-songwriter showcase KL Sing Song was launched. Organized by a trio of singer-songwriters, Kugan, Tan, and Azmyl Yunor, at the International College of Music (ICOM), KL Sing Song offered a stage to performers whose music was hardly ever broadcast by the mainstream media.

The Kuala Lumpur singers and songwriters, ranging from award-winning performers such as Yuna to upcoming youngsters and seasoned street buskers, emphasize the use of original compositions and minimal instrumental accompaniment. In contrast to the more visible, but politically less engaged Malaysian indie rock scene, the singer-songwriter scene has accommodated political communication and satire, hence providing an alternate cultural space notably supported by alternative online media, non-governmental organizations, and non-commercial venues throughout the Malaysian Klang Valley.

It was against this background and during her law studies at the Technological University Mara that Yuna first took up the acoustic guitar playing her self-composed songs in bars and at festivals. Early interviews focus on Yuna as both the girl-next-door and a devout girl who sees no problem in wearing a hijab ('headscarf') on stage as a symbol of her Muslim identity. It is this image of an ordinary yet 'hijabista' celebrity that Yuna continues to cultivate.

That said, Yuna may have been confined to playing at such local venues had she not resorted to promoting her own music through social media. While participation in the talent show 
One in a Million in 2006 did not bring the success that she had hoped for, it is through her own MySpace music channel that, around the same time, her career first took off. Starting with a cover of Indonesian band Peterpan, she soon started adding her own songs and produced the mini-album Yuna EP, only available through email order. However, in 2008, Yuna's mini-album was also up for an official release on CD, and one of the album's tracks, 'Deeper Conversation', an acoustic ballad featuring a strong melody and subtle guitar playing, even earned her a national award for 'Best Local English Song'. Like her KL singer-songwriter peers, Yuna writes both in Malay and English and her songs fit in seamlessly with the global musical and textual sensibilities of the indie/alternative pop genre. Klang Valley and a MySpace account gained her national fame, and she opened her own shop - 'Iamjetfuel' - in Subang Jaya. But the rest of the world also seemed willing to embrace this Malay Muslim girl-next-door. Eventually, it was US indie pop record label Fader that offered her a contract. In 2012, her first US single was released, 'Living your Life', a track produced by well-known R\&B and urban artist Pharrell Williams. Three full 'international' albums quickly followed suit and today Yuna divides her time between doing gigs in LA and running her newly opened online store Novemberculture. com from the same Kuala Lumpur suburb where she started her career, still selling hijabs ('modern and modest'), jumpsuits, and skirts, but also her much favoured Tiny Forrest Terrariums.

Yuna is still a fervent user of social media, cherishing the contact with her followers, or 'Yunalisers' as she affectionately calls them, and feeding them with Islamic wisdoms such as, 'It is forbidden for you to eat with your plates full, while your neighbour starves.' In spite of her newly gained fame as one of the internationally most famous Malaysian singers ever, she keeps much of her profile intact. Internationally, she is considered as 'one of those lucky MySpace songwriters who made it', while Al Jazeera dubbed her a 'Muslim star'. At home, she is an ambassador of Malaysia, finding pride in producing a 100 per cent Malaysian-made music clip and contributing the song 'KL Kita' ('Our Kuala Lumpur') to a film anthology on 
the lives and hopes of the inhabitants of the Malaysian capital. In the person of Yuna, then, we find the present state of Southeast Asian pop, no longer confined to language or locality, but with a distinct character of its own and the world as its playground.

\section{Box 4.1 JKT48}

The idol group JKT48 was founded in 2011 as an Indonesian franchise of the Japanese idol group AKB48, and the first of several such international 'sister groups' abroad. JKT 48 is closely styled after the girl-next-door and 'cute' (kawaii, Japanese) appeal of its Japanese sister, and, similarly, promotes the ideal of idols that can be easily approached by their fans. JKT48 provides daily entertainment in its own Jakarta-based theatre situated at the $\mathrm{fX}$ Sudirman shopping mall, targeting an audience of teenagers and young single men. The group is very much a fan-driven effort. The group's official website (both in Japanese and Indonesian) claims that it was launched 'in the spirit of creating a platform through which Indonesian women could realize their ambitions. Together with our fans we would like to create an all-Indonesian idol.' As with AKB48, JKT48 consists of distinct teams. Fans rank the more than 70 members, and the number one team will record the next single, with the most popular girl (also by vote) on this occasion taking centre stage. So far, JKT48 has recorded two albums. The first album mostly contains Indonesian renderings of songs by ABK 48 and sister groups; a second minialbum, Gingham Check released mid-2014, made it to the number two position in Indonesia's iTunes Charts. JKT48's first feature movie, VIVA JKT 48 , telling the fictional story of the band's members reclaiming their own theatre, was released around that time as well. Despite much of the grassroots rhetoric of a fan-driven sensation, the JKT 48 craze seems to be carefully orchestrated by Japanese and Indonesian authorities aiming at a closer relationship between the two nations. JKT 48 and other franchises are seen as part of the Japanese government's 'Cool Japan' approach to promote Japanese culture around the world, an effort much supported by Japanese companies that widely regard Indonesian youth culture as a next 
big market. JKT48 thus regularly appears in television advertisements for Japanese companies, among them Pocari, Sharp, and Yamaha. In Japan, the girls of JKT48 were made ambassadors for the Enjoy Jakarta tourism programme, which was part of an effort to attract more Japanese visitors to Indonesia's capital.

\section{Box 4.2 An Indonesian indie song}

In 2000, the euphoria of the Indonesian political Reformasi ('reformation') was in full swing when the signature tune of the alternative rock band Sheila On 7 from Yogyakarta, 'Sephia', was released. Written by the band's guitarist Eross Candra, the song came out at a time when media and the arts enjoyed an unprecedented degree of freedom. This may have emboldened Candra to write explicit lyrics (by Indonesian standards) about a love triangle, a subject that had previously been considered taboo in mainstream Indonesian culture. The song clearly struck a note with young people wishing to free themselves from traditional social constraints. The almost mystical aura surrounding the song was reinforced by an urban legend about a supernatural event involving a fan of the band who had recently committed suicide. Various journalists, bloggers, and literary critics have since offered interpretations of the song's significance as a potent symbol of the mind-set of modern Indonesian youth.

\section{Box 4.3 Karaoke discs}

Video CDs held a similarly democratizing potential as the cassette tapes of the early 1970s, providing a cheap means to distribute music clips for those lacking broadband internet connection. Most VCDs contained karaoke music ('empty orchestra', Japanese). They offered the possibility to turn off the audio channel with the sound of the vocalist, and just hear the accompaniment and see the images and text. Thus, one could sing along with the accompaniment, like earlier karaoke cassette tapes. The latter invaded the Japanese domestic sphere in the 1980s, and, not long after, the craze hit the coasts of Indonesia. After its introduction on cassette tape in Southeast Asia, karaoke 
Illustration 13 Video CD vendor in a market stall

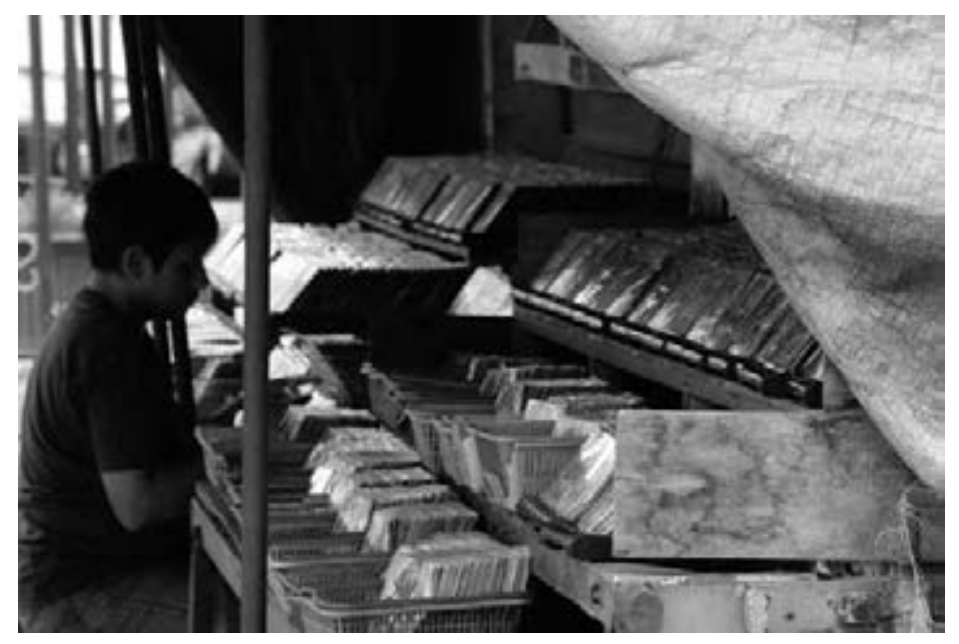

Photo by Bart Barendregt

continued to play a role in the promotion of the more expensive laser disc around 1995, and eventually the VCD from around 1997.

\section{Box 4.4 SoundCloud communities}

SoundCloud communities are an illustration of how social media are used today by a young generation of musicians not only to connect to a larger world, but also to re-introduce a certain sense of locality. SoundCloud is a social media site where musicians may upload their own recordings, up to $120 \mathrm{MB}$, without additional costs. It is possible to 'like' and promote other artists' music by reposting the song and by making it visible in one's own profile. This way, the song is shared with all users who follow that account and can spread fast through an increasingly larger network. Most Southeast Asian acts have their own SoundCloud accounts to share music with friends and family. But with the knowledge that scouts are constantly monitoring the accounts and some songs going viral, these aspiring artists also hope that, one day, it will help them to get offered a record deal. 
Inspired by the example of European and American peers, a group of young amateur musicians from Yogyakarta launched the idea for a local SoundCloud community, SoundCloudYK, in November 2013. It enabled a local community, already well connected through social media, to meet each other face-to-face, while listening to each other's music. Such offline meetings followed earlier initiatives where online collaboration led to joined ventures, such as ten covers of the same song or a one-hour live stream of local SoundCloud songs that were broadcast daily at campus radio. SoundCloud facilitates such initiatives through monthly SoundCloud Meetups, offline sessions that focus on anything from vocal training to ethnically inspired music. Three-monthly SoundCloud Shows are public events that bring together local acts and local music fans. Mostly staged at local cafes, these shows provide fledgling musicians with a venue. Next to the stage a projector beams incoming Twitter feeds, a clear illustration that these gatherings are rooted in the social media sphere. Anyone with a SoundCloud account can climb the stage!

Illustration 14 \#SoundCloud Meetup YK in the Momento Café, Yogyakarta, 26 February 2014

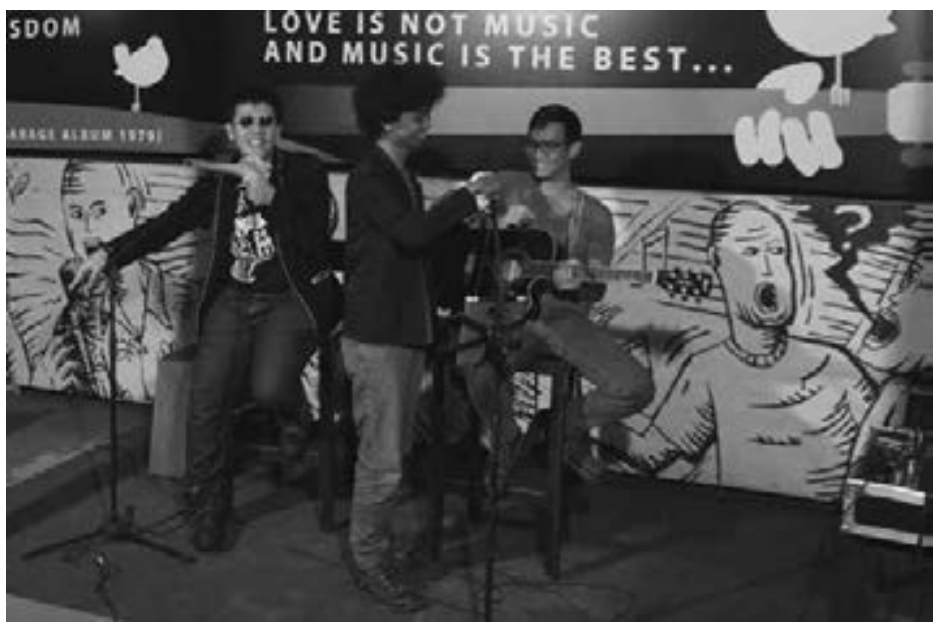

Photo by Bart Barendregt 



\section{Selected Bibliography}

Arps, Bernard. 2009. "Osing Kids and the Banners of Blambangan: Ethnolinguistic Identity and the Regional Past as Ambient Themes in an East Javanese Town.” Wacana 11.1: 1-38.

Baker, C., and Pasuk Phongpaichit. 2009. A History of Thailand. Cambridge: Cambridge University Press.

Barendregt, Bart. 2002. "The Sound of 'Longing for Home': Redefining a Sense of Community Through Minang Popular Music." Bijdragen tot de Taal-, Land-en Volkenkunde/Journal of the Humanities and Social Sciences of Southeast Asia 158.3: 411-450.

— 2012. "Sonic Discourses on Muslim Malay Modernity: The Arqam Sound." Contemporary Islam 6.3: 315-340.

Barendregt, Bart, ed. 2014. Sonic Modernities in the Malay World: A History of Popular Music, Social Distinction and Novel Lifestyles (1930s-20oos). Vol. 290 of Verhandelingen van het Koninklijk Instituut voor Taal-, Land-en Volkenkunde, vol. 5 of Southeast Asia Mediated, edited by Bart Barendregt and Ariel Heryanto. Leiden and Boston: Brill.

Barendregt, Bart, and Wim van Zanten. 2002. "Popular Music in Indonesia since 1998, in Particular Fusion, Indie and Islamic Music on Video Compact Discs and the Internet." Yearbook for Traditional Music 34: 67-113.

Baulch, Emma. 2007. Making Scenes: Reggae, Punk, and Death Metal in 1990 s Bali. Durham: Duke University Press.

- 2010. "Music for the Pria Dewasa: Changes and Continuities in Class and Pop Music Genres." Journal of Indonesian Social Sciences and Humanities 3: 99-130.

— 2014. "Pop Melayu vs. Pop Indonesia: New Interpretations of a Genre into the 200os." In Sonic Modernities in the Malay World: A History of Popular Music, Social Distinction and Novel Lifestyles (1930s-20oos), edited by Bart Barendregt, 187-216. Vol. 290 of Verhandelingen van het Koninklijk Instituutvoor Taal-, Landen Volkenkunde, vol. 5 of Southeast Asia Mediated, edited by Bart Barendregt and Ariel Heryanto. Leiden and Boston: Brill.

Cohen, Matthew Isaac. 2002. "Border Crossings: Bangsawan in the Netherlands Indies in the Nineteenth and Early Twentieth Centuries." Indonesia and the Malay World 30: 101-115.

— 2006. The Komedie Stamboel: Popular Theatre in Colonial Indonesia, 1891-1903. Leiden: KITLV Press.

Day, Tony, and Maya Liem, eds. 2010. Cultures at War: The Cold War and Cultural Expression in Southeast Asia. Ithaca: Cornell University Press.

Enriquez, E.L. 2008. Appropriation of Colonial Broadcasting: A History of Early Radio in the Philippines, 1922-1946. Quezon City: The University of the Philippines Press. 
Frederick, William H. 1982. "Rhoma Irama and the Dangdut Style: Aspects of Contemporary Indonesian Popular Culture." Indonesia 34: 102-30.

Gaisberg, Fred. 1942. The music goes round. New York. The MacMillan Company. Harnish, D.D., and A.K. Rasmussen, eds. 2011. Divine Inspirations: Music and Islam in Indonesia. New York: Oxford University Press.

Heryanto, Ariel. 2014. Identity and Pleasure: The Politics of Indonesian Screen Culture. Singapore: NUS Press.

Johan, Adil. 2014. "Disquieting Degeneracy: Policing Malaysian and Singaporean Popular Music Culture From the Mid-196os to Early-1970s." In Sonic Modernities in the Malay World: A History of Popular Music, Social Distinction and Novel Lifestyles (1930s-20oos), edited by Bart Barendregt, 135-161. Vol. 290 of Verhandelingen van het Koninklijk Instituut voor Taal-, Land-en Volkenkunde, vol. 5 of Southeast Asia Mediated, edited by Bart Barendregt and Ariel Heryanto. Leiden and Boston: Brill.

Kanahele, G.S. 1979. Hawaiian Music and Musicians: An Illustrated History. Honolulu: The University of Hawaii.

Keppy, Peter. 2008. "Keroncong, Concours and Crooners: Home Grown Entertainment in Twentieth-Century Batavia." In Linking Destinies: Trade, Towns and Kin in Asian History, edited by P. Boomgaard, D. Kooiman and H. Schulte Nordholt, 141-158. Leiden and Boston: KITLV Press.

- 2013. "Southeast Asia in the Age of Jazz." Journal of Southeast Asian Studies 44.03: 444-464.

Khiun, Liew Kai. 2003. "Limited Pidgin-Type Patois? Policy, Language, Technology, Identity and the Experience of Canto-pop in Singapore." Popular Music 22.02: 217-233.

Lockard, Craig A. 1996. "Popular Musics and Politics in Modern Southeast Asia: A Comparative Analysis." Asian Music 27.2: 149-199.

— 1998. Dance of Life: Popular Music and Politics in Southeast Asia. Honolulu: University of Hawaii Press.

Luvaas, Brent. 2013. DIY Style: Fashion, Music and Global Digital Cultures. London: A\&C Black.

MacLachlan, H. 2011. Burma's Pop Music Industry: Creators, Distributors, Censors. Rochester: University of Rochester Press.

Manuel, Peter, and Randall Baier. 1986. “Jaipongan: Indigenous Popular Music of West Java." Asian Music 18.1: 91-110.

Martin-Iverson, Sean. 2014. "Bandung Lautan Hardcore: Territorialisation and Deterritorialisation in an Indonesian Hardcore Punk Scene." Inter-Asia Cultural

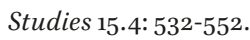

Mitchell, J. 2009. "Thai Television and pleeng luuk tung: The Role of Television in the Isan Cultural Revival." Perfect Beat 10.1: 81-101.

Moore, Rebekah E. 2013. "My Music, My Freedom(?): The Troubled Pursuit of Musical and Intellectual Independence on the Internet in Indonesia." Asian Journal of Communication 23.4: 368-385. 
Mulyadi, M. 2009. Industri Musik Indonesia: Suatu Sejarah. Bekasi. Koperasi Ilmu Pengetahuan Sosial.

Ng, Benjamin Wai-ming. 2002. "Japanese Popular Music in Singapore and the Hybridization of Asian Music.” Asian music 34.1: 1-18.

Sarkissian, Margaret. 2005. "Religion Never Had It so Good': Contemporary Nasyid and the Growth of Islamic Popular Music in Malaysia." Yearbook for Traditional Music 37: 124-152.

Sooi Beng, Tan. 1996-97. "The 78rpm Record Industry in Malaya Prior to World War II." Asian Music 1: 1-42.

— 2005. "From Folk to National Popular Music: Recreating Ronggeng in Malaysia 1." Journal of Musicological Research 24-3-4: 287-307.

Spottswood, Richard K. 1990. Ethnic music on records: a discography of ethnic recordings produced in the United States, 1893-1942. Urbana. University of Illinois Press. Vol. 4-6.

Sutton, R. Anderson. 2002. "Popularizing the Indigenous or Indigenizing the Popular? Television, Video, and Fusion Music in Indonesia.” Wacana Seni/ Journal of Arts Discourse 1: 13-31.

Tyson, Adam D. 2011. "Titik Api: Harry Roesli, Music, and Politics in Bandung, Indonesia." Indonesia 91: 1-34.

Wallach, Jeremy. 2008. Modern Noise, Fluid Genres: Popular Music in Indonesia, 1997-2001. Madison: University of Wisconsin Press.

Wallach, Jeremy, and Esther Clinton. 2013 "History, Modernity, and Music Genre in Indonesia: Popular Music Genres in the Dutch East Indies and Following Independence." Asian Music 44.2: 3-23.

Wee, C.J.W.L. 1999. "Representing the 'New' Asia: Dick Lee, Pop Music and a Singapore Modern." Transnational Asia Pacific: Gender, Culture and the Public Sphere, edited by Shirley Geok-lin Lim, Larry E. Smith, and Wimal Dissanayake, 111-133. Urbana and Chicago: University of Illinois Press.

Weintraub, Andrew N. 2010. Dangdut Stories: A Social and Musical History of Indonesia's Most Popular Music. New York: Oxford University Press.

— 2014. "Pop Goes Melayu: Melayu Popular Music in Indonesia, 1968-1975." In: Sonic Modernities in the Malay World: A History of Popular Music, Social Distinction and Novel Lifestyles (1930s-20oos), edited by Bart Barendregt, 165-186. Vol. 290 of Verhandelingen van het Koninklijk Instituut voor Taal-, Land- en Volkenkunde, vol. 5 of Southeast Asia Mediated, edited by Bart Barendregt and Ariel Heryanto. Leiden and Boston: Brill.

Weintraub, Andrew N., ed. 2011. Islam and Popular Culture in Indonesia and Malaysia. London: Routledge.

Williams, Sean. 1989. "Current Developments in Sundanese Popular Music." Asian Music 21.1: 105-136.

Yampolsky, Philip. 1987. Lokananta: A Discography of the National Recording Company of Indonesia, 1957-1985. Madison: University of Wisconsin.

— 1989. "Hati yang Luka: An Indonesian Hit." Indonesia 47: 1-17. 
— 2001. "Can the Arts Survive, and Should They?" Indonesia 71: 175-185.

— 2010. "Kroncong Revisited: New Evidence from Old Sources." Archipel 79: 7-56.

- 2013 Music and Media in the Dutch East Indies: Gramophone Records and Radio in the Late Colonial Era, 1903-1942. PhD diss., University of Washington.

— 2014 "Music on Dutch East Indies Radio in 1938: Representations of Unity, Disunity, and the Modern." In Sonic Modernities in the Malay World: A History of Popular Music, Social Distinction and Novel Lifestyles (1930s-20oos), edited by Bart Barendregt, 47-112. Vol. 290 of Verhandelingen van het Koninklijk Instituut voor Taal-, Land- en Volkenkunde, vol. 5 of Southeast Asia Mediated, edited by Bart Barendregt and Ariel Heryanto. Leiden and Boston: Brill.

Zin, Min. 2002. "Burmese Pop Music: Identity in Transition." Irrawaddy Sept, 10.7. 